\title{
MOLÉSTIAS DE VIRUS DO FUMO NO ESTADO DE SÃO PAULO
}

A. S. Costa.

\section{INTRODUÇ $\tilde{A} O$}

Diversas moléstias de virus do fumo (Nicotiana tabacum L.) foram constatadas em São Paulo, tendo sido descritas em publicações esparsas $(2,3,4,5,6,13,17,21,22)$. Atualmente, está em andamento um grande plano de estudo sôbre a cultura do fumo, plano êsse que vem sendo executado em cooperação, por diversos técnicos da Escola Superior de Agricultura "Luiz de Queiroz", do Instituto Agronômico, do Instituto Biológico e da Divisão do Fomento Agrícola. No decorrer das experiências já realizadas, foi notada a falta de uma publicação que reunisse as informações existentes sôbre as moléstias de virus do fumo, de maneira a facilitar a estandardização das observações efetuadas por diversas pessoas, nas diferentes experiências. É esta, portanto, a finalidade precípua dêste trabalho. Entretanto, apresentamos, a título sugestivo, algumas medidas de contrôle para as diferentes moléstias.

Ao autor coube preparar êste trabalho, para cuja feitura foram aproveitadas, livremente, as informações contidas nas publicações acima citadas.

\section{VIRA-CABEÇA}

Em certas localidades é a moléstia de maior importância na cultura do fumo. Está bastante espalhada no Estado de São Paulo, onde a sua existência já é conhecida há muitos anos. É sabido que o mesmo virus ocorre também em outros Estados, como na Bahia, Pernambuco, Rio. de Janeiro e Rio Grande do Sul. Em São Paulo, vira-cabeça já foi observada nos seguintes municípios: Campinas, Tietê. Piracicaba, Limeira, Tupí, Sorocaba, Pitangueiras, Pirangí, Ibitirama, Santa Lúcia, São Roque, Bragança, Cunha, Formosa, Iacanga, Itapira, Mococa, São Bento. do Sapucaí, São Carlos, Socorro e Tapiratiba. 
Sòmente o fumo é atacado por esta moléstia. O mesmo virus é capaz de infetar o tomateiro (Lycopersicon excuienlum Mill.), a batatinha (Solanum 'tuberosum L.), numerosas outras Silanacex e muitas plantas ornamentais. Muitas hervas daninhas são tãmbém hospedeiras dêste virus, tais como a maria-pretinha (Solanum riigrum L.), o estramônio (Jatura stramonium L.) e o carurú (Amaranth's sp.). Ataques graves de vira-cabeça em plantas de carurú e estramônio já têm sido verificados. Observações feitas em 1941, num campo no qual numerosas plantas de Malura slramonium cresciam espontâneamente, mostraram que cêrca de $30 \%$ das plantas estavam afetadas por vira-cabeça.

A importância econômica de vira-cabeça é: devida, principalmente, ao grande número de plantas mortas pela moléstia. Em plantações atacadas, a percentagem de plantas atetadas pode atingir $50 \%$ ou mais. A maioria destas morre, principalmente se são atacadas quando novas. O número de plantas que sobrevivem à moléstia, isto é, que se restabelecem, é variável, dependendo da idade e das condições do ambiente. Plantas restabelecidas perdem, porém, o seu valor, pois as fôlhas são de qualidade inferior.

\section{Sintomas}

Em qualquer idade, as plantas podem ser afetadas. A moléstia é, todavia, mais comum em viveiros ou em plantações novas. Com o aumento da idade, as plantas adquirem uma certa resistência; quando adultas, são raramente afetadas. É principalrnente nos primeiros cinquenta dias depois de transplantadas que são mais notados os ataques.

A planta afetada por vira-cabeça cessa c crescimento. As tôlhas do tôpo da planta arqueam-se para baixo. Frequentemente, é tôda a parte superior da planta que se torce em direção ao solo, fato êsse que originou os nomes de vira-cabeça ou vira-coka, dados à moléstia. As fôlhas novas mostram concomitantemente palidez das nervuras, rugosidade e necrose. Necrose também se manifesta nas fôlhas médias. Listas pretas, formadas ao longo da haste, são c smuns em plantas adultas afetadas. A necrose das fôlhas apresenta-se sob forma variada: riscas ao longo das nervuras de terceira ordem, faixas paralelas às nervuras de primeira e segunda ordem ou como anéis simples ou concêntricos. Um amarelecimento de tôda a planta é tambér. sintoma frequente, precedendo, geralmente, a morte desta. 


\section{Etiologia}

O virus de vira-cabeça pertence ao grupo do virus de "spottedwilt" (Lethum australiense H.). Em São Paulo é disseminado por uma espécie de tripes, Frankliniella sp. Êste inseto é também capaz de viver sôbre várias outras plantas. Ainda não sabemos se outras espécies de tripes podem também servir de vetores de vira-cabeça.

\section{Contrôle}

As variedades de fumo são, na sua maioria, altamente suscetíveis a vira-cabeça. Algumas variedades do grupo Sumatra mostram alguma resistência que, contudo, está longe de ser satisfatória $(1,18)$.

Entre as espécies de Nicotiana ensaiadas quanto à sua resistência a vira-cabeça, $N$. glauca foi a única que se mostrou de valor. Pode-se dizer que esta espécie é pràticamente imune a vira-cabeça, se bem que já tenhamos observado sintomas em algumas plantas. A seguir apresentamos os dados obtidos sôbre vira-cabeça, em um ensaio com diferentes espécie de Nicoliana, realizado na Estação Experimental Central em Campinas, no ano de 1939:

\section{Espécie}

Percentagem de vira-cabeça

Nicotiana glauca

N. rustica (N. ${ }^{\circ}$ 264)

8,5

N. langerdorfii

N. syl'cestris'

V. rustica (N.'25)

V. tabacum var. Samsoun

17,9

I. glulinosa

I. longijlora

1. labacum var. Geudertheimer

N. repanda ................. 56,9

I. nudicaulis.

Alguns trabalhos foram iniciados para se ver se seria possível obter a transferência da alta resistência de $\boldsymbol{N}$. glauca a vira-cabeça, para variedades comerciais de fumo. Para êste fim usou-se o alotetraplóide Tabacum x Glauca ( $\left.{ }^{*}\right)$ como ponte, assim como no caso da transferência do fator $\mathbf{N}$ (reação necrótica ao virus do mosaico comum do fumo) de 1 . glutinosa para fumo (14). Êste é, porém, um trabalho demorado e que poderá produzir resultados sòmente depois de muitos anos.

(*) As sementes dêste alotetraplóide foram obtidas por gentileza do dr. H. H. Smith, do Bureau of Plant Industry, U. S. Departament of Agriculture. 
Orrancamento das plantas afetadas por vira-cabeça é uma medida de contrôle aconselhável. Deve ser feito loço de início, assim que se percebam os sintomas da moléstia. As plartas arrancadas deven ser recolhidas imediatamente num saco e posteriormente eliminadas. É desaconselhável arrancar as plantas doentes e deixálas sôbre o solo, nas proximidades das plantas sadias. Os vetores que se acham sibre as plantas arrancadas, e deixadas sôbre o sclo, passam para as saciáas, assim que aquelas principiam a murchar. Desta maneira é muito rrovável que venham a infetar outras plantas.

Fawcett $(9,10)$ verificou que a sombra oferece uma certa protes contra a "corcova" na Argentina. Plantas cultivadas à sombra i:ostram-se menos atacadas que plantas similares no sol. Está ainda para ser verificado se c efeito é sôbre a resistência da planta ou sôbre o vitor.

É relativamente fácil controlar-se o vetor de vira-cabeça no viveiro. Já no campo o seu contrôle oferece muito ma ores dificuldades. $O$ combate ao vetor na fase do viveiro não tem, aparentemente, nenhuma influência sôbre a incidência da moléstia em campo. Isto foi verificado em diversas experiências. Plantas criadas em caixas à prova de insetos, quando levadas para o campo, mostraram a mesma percentagem de vira. cabeça que as plantas formadas em viveiro comum, no qual abunciava o tripes vetor da moléstia. Nestas experiências, os lotes criados à provà de insetos foram transplantados próximos aos do viveiro comum, mas separados uns dos outros por meio de barreiras ce Crolalaria juncea. Fistas tinham por finalidade evitar a passagem de vetores dos lotes não tratados para os criados à prova de insetos, no viveiro. Em outras expe. riências, mudas criadas à prova de insetos foram transplantadas para local mais ou menos isolado na Estação Expenimental Central eni Campinas. Entretanto, depois de cêrca de oito dias (mais ou menos o períccio de incubação da moléstia) muitas plantas principiaram a mostrâr sintomas de vira-cabeça. Êstes fatos mostraram que no campo existe uma população do inseto vetor, que, provàvelmer.te, vive sôbre hervas daninhas, passando destas para o fumo. Mostrarn também que muitos dos insetos se acham virulíferos, obtendo o virus com tôda certeza das plantas nativas suscetíveis.

$O$ contrôle do tripes vetor de vira-cabesa pode ser tentado pelo uso de inseticidas de contacto ou repelentes. Muitos inseticidas já têm sido ensaiados em forma líquida ou em pó, no contrôle dos vetores das moléstias do grupo do virus do "spotted-wilt". Moore (20) ensaiou diversas substâncias, mas, devido à baixa incidência da moléstia no 


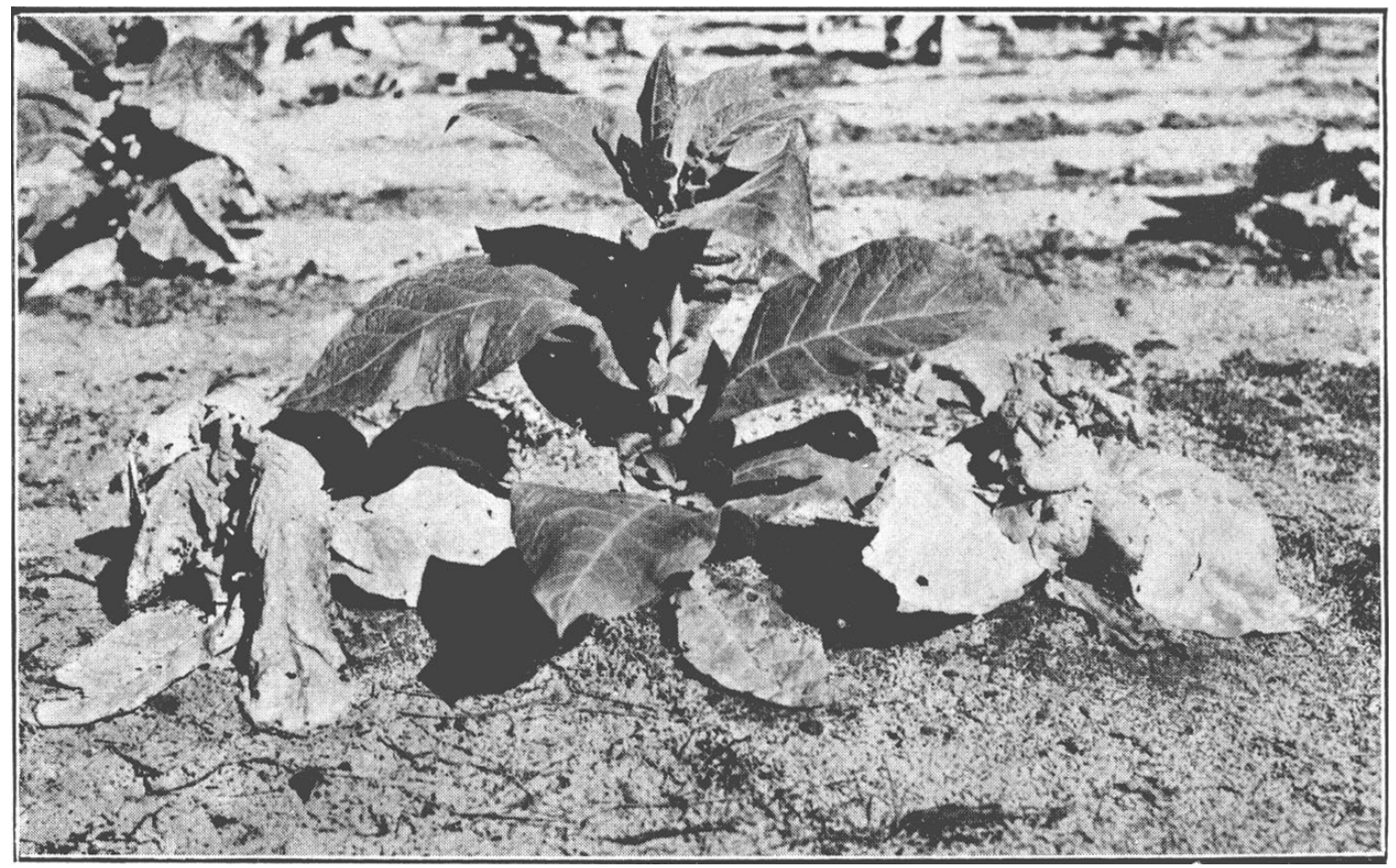

Figura 1 -... Nicoliana labacum var. Virginia. (Uma planla sadia entre duas afetadas, mostrando os sintomas de vira-cabeça).

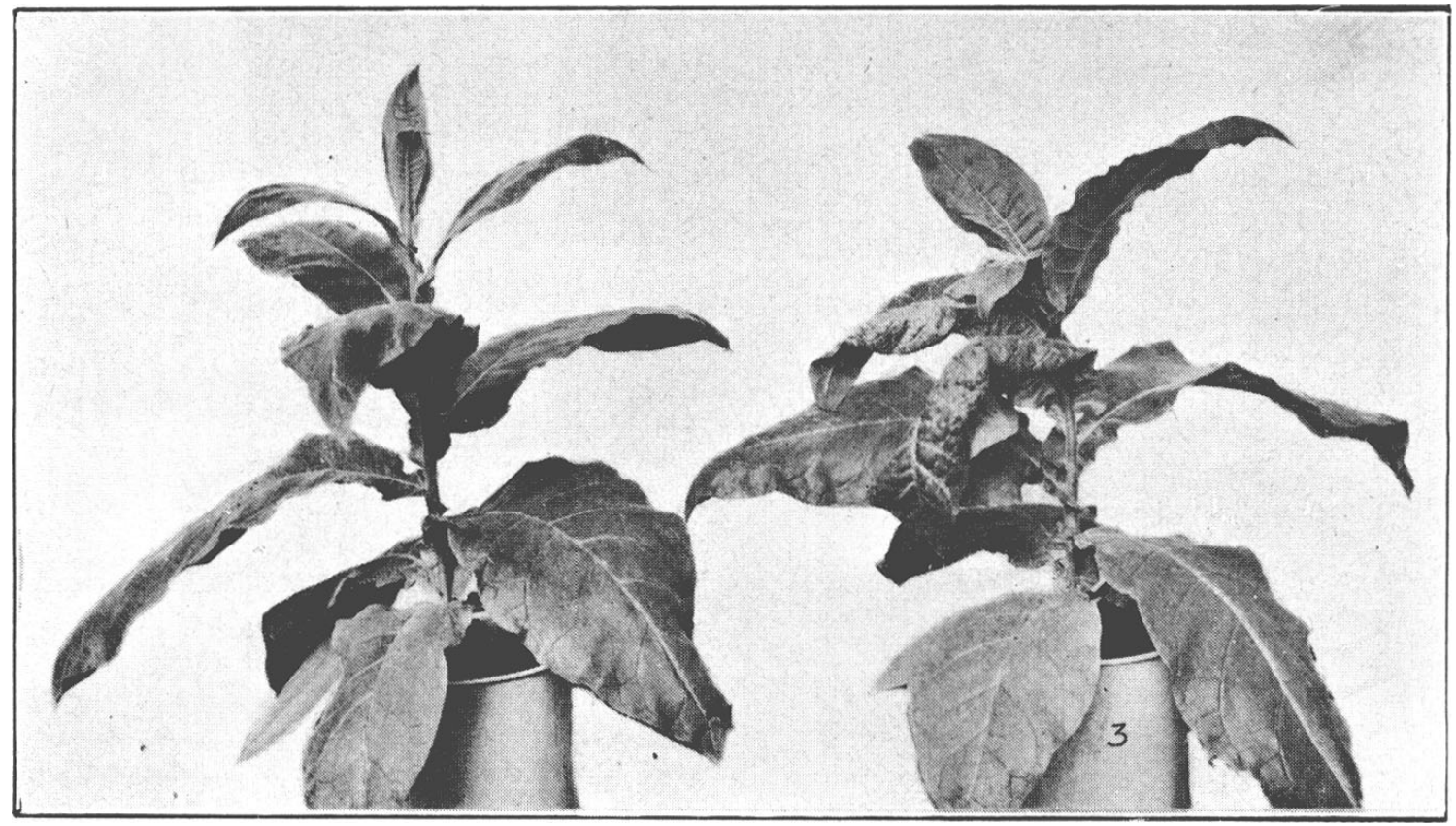

Figura 2 -... Vicotiana labacum var. I'irginia. (Uma planta afetada ao lado de uma planta sadia. - Notar a curvatura da parte superior da planta). 


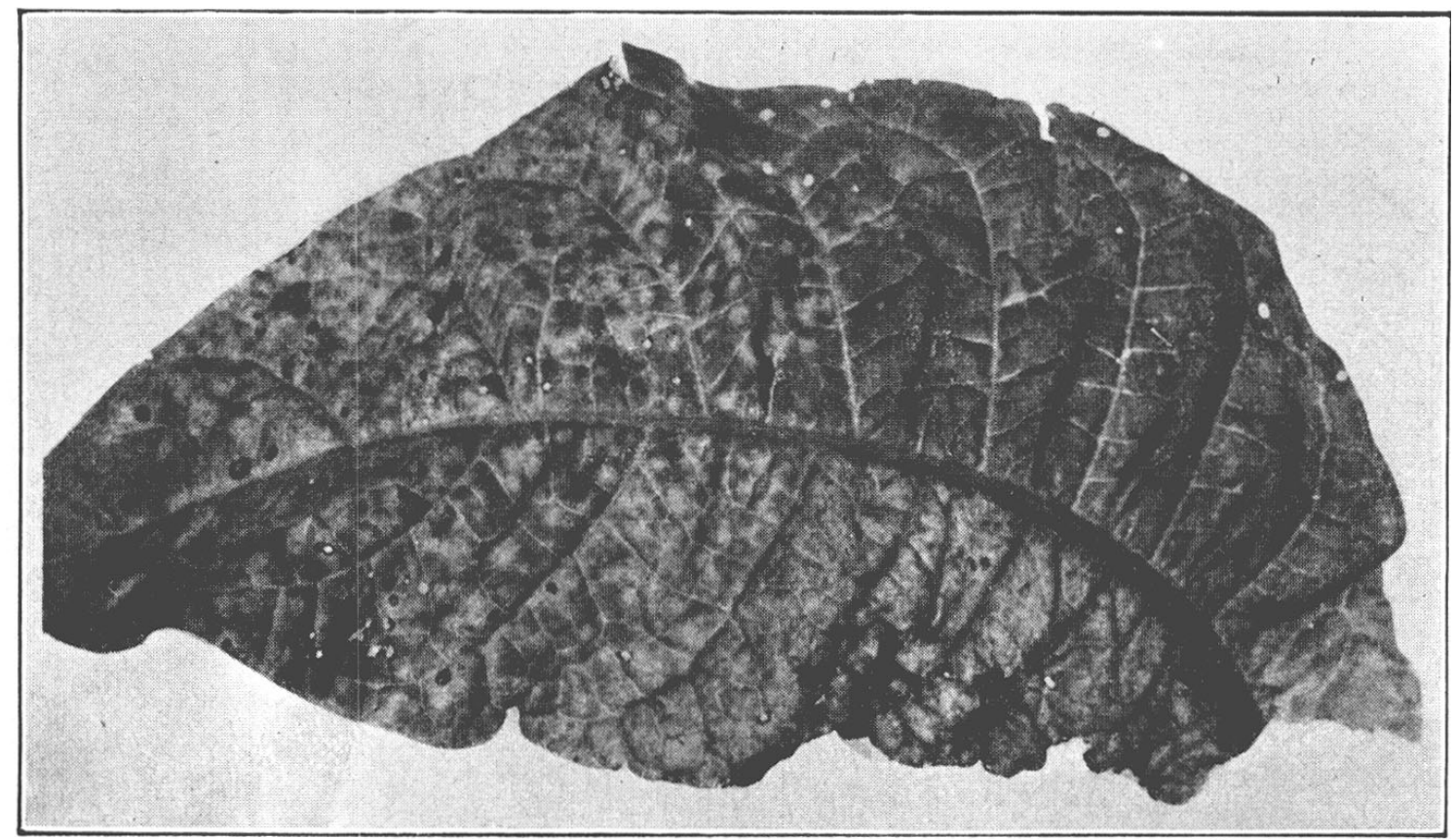

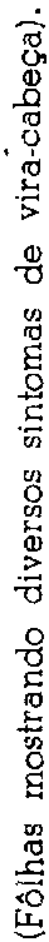

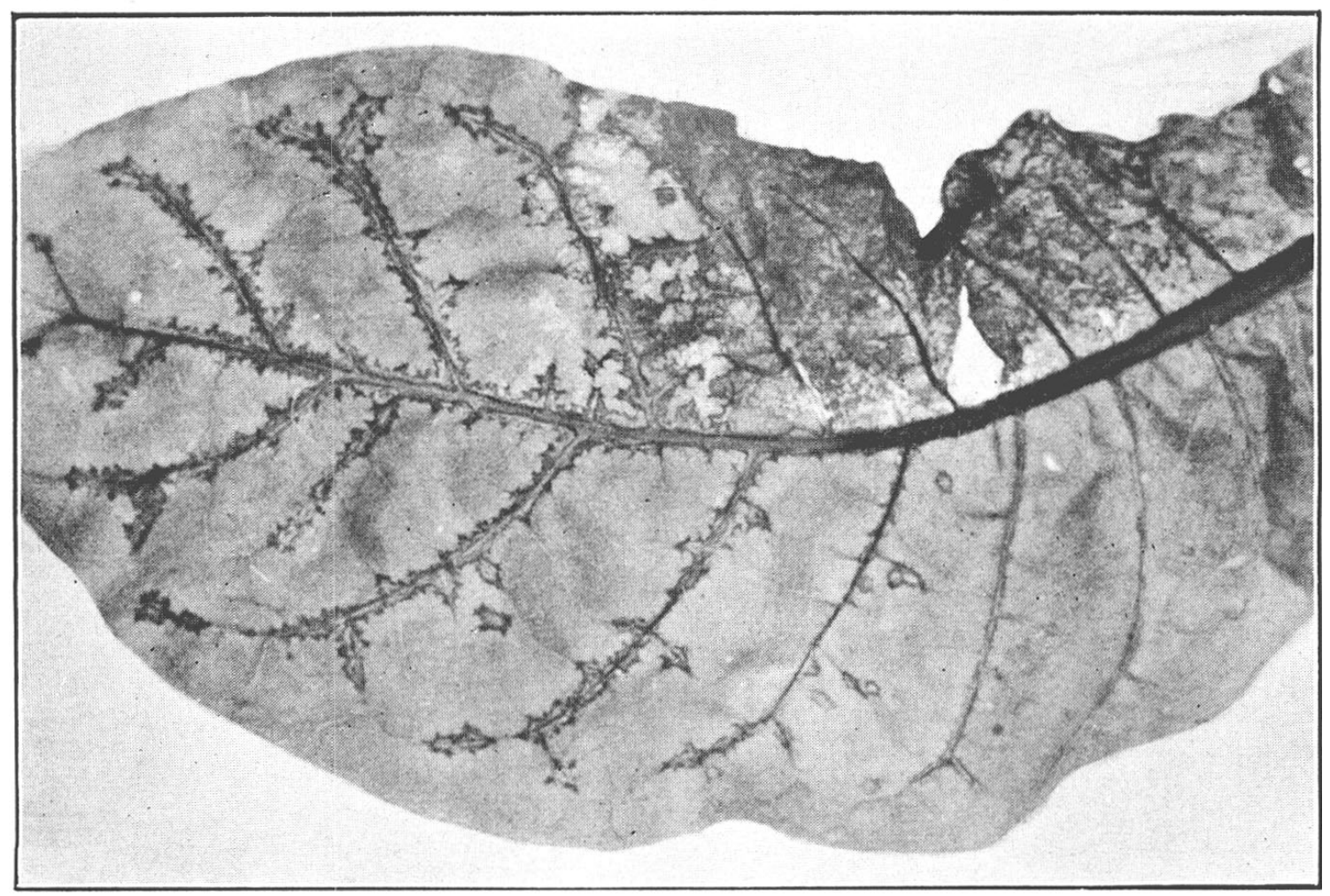

 


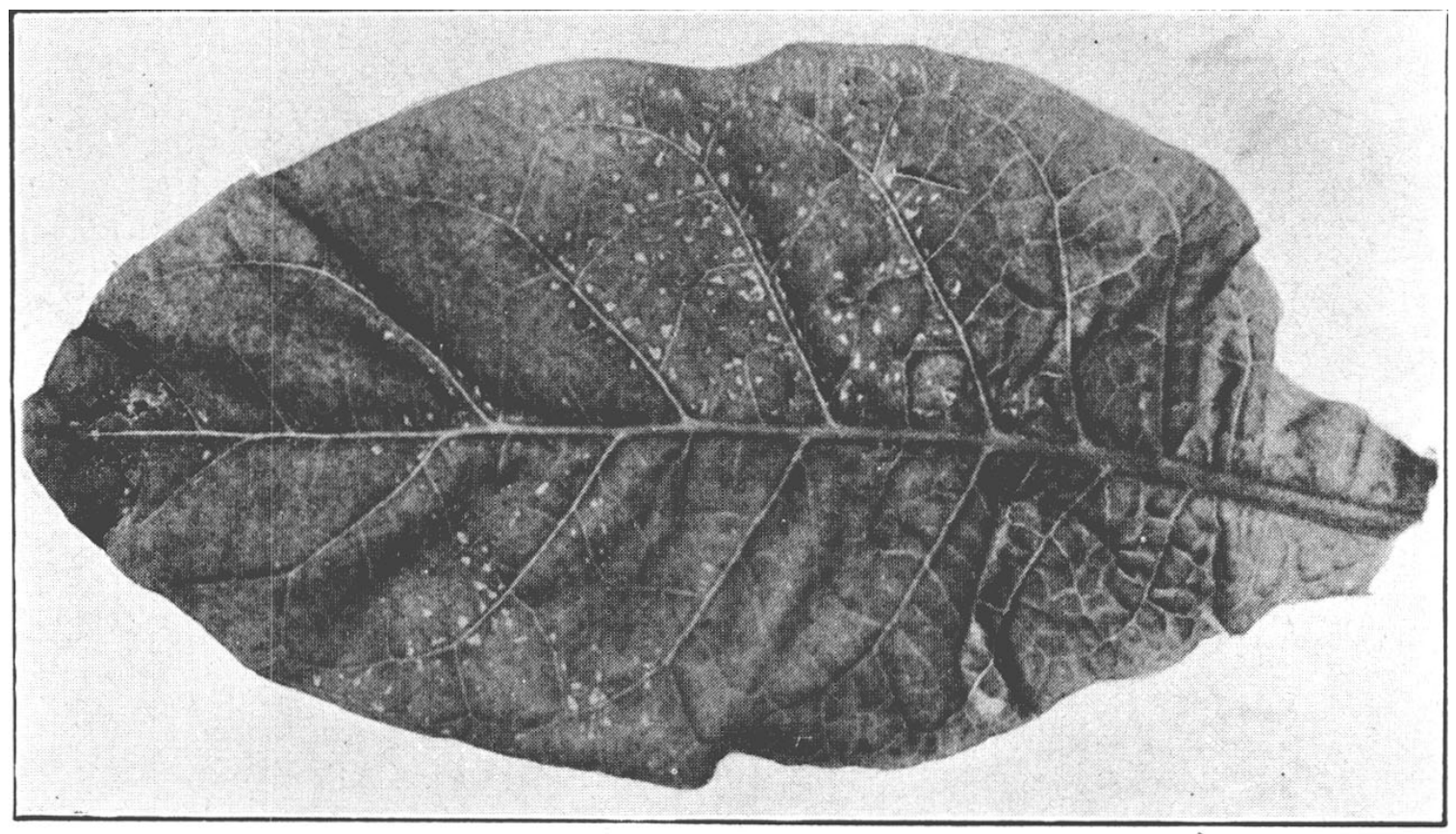

वे

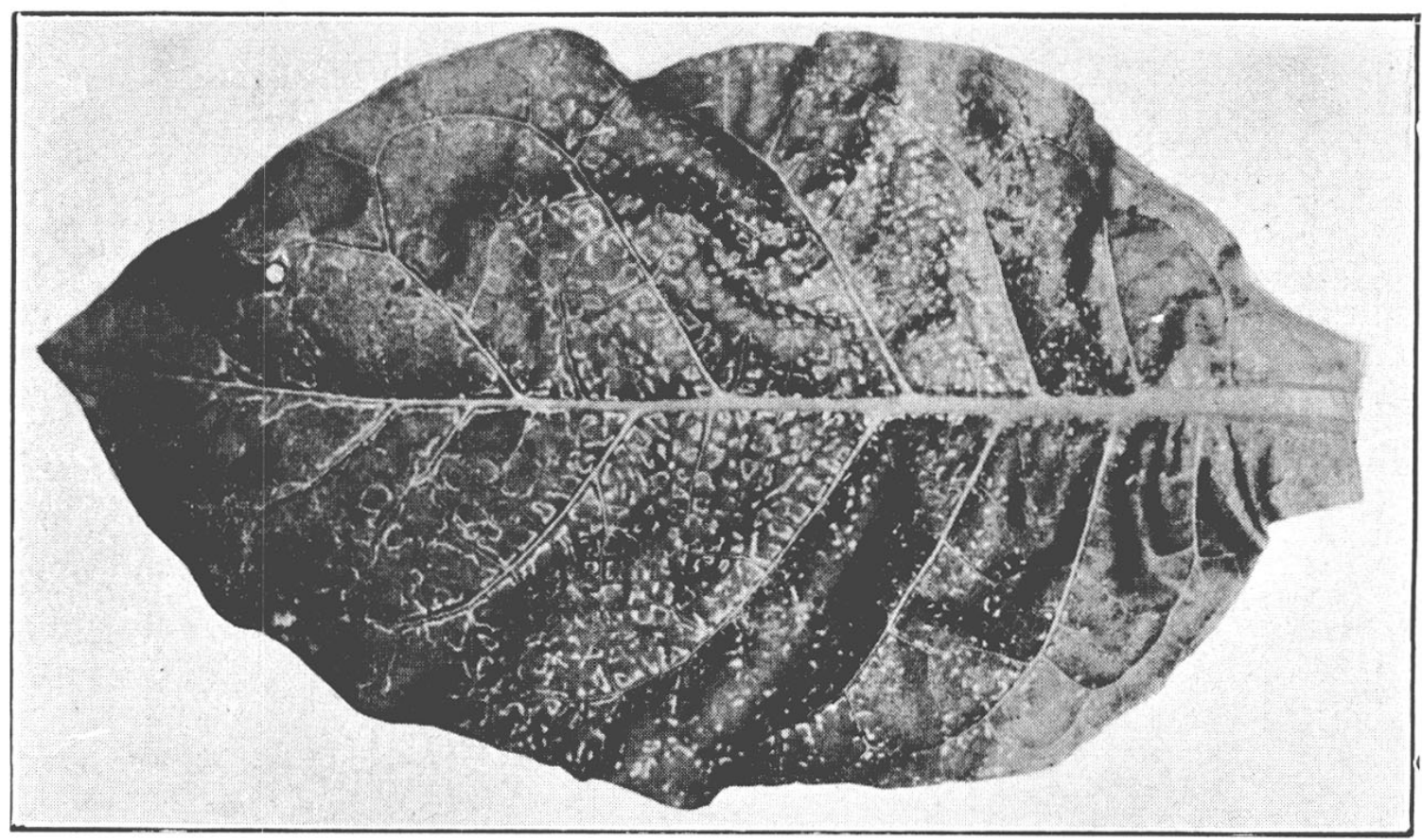




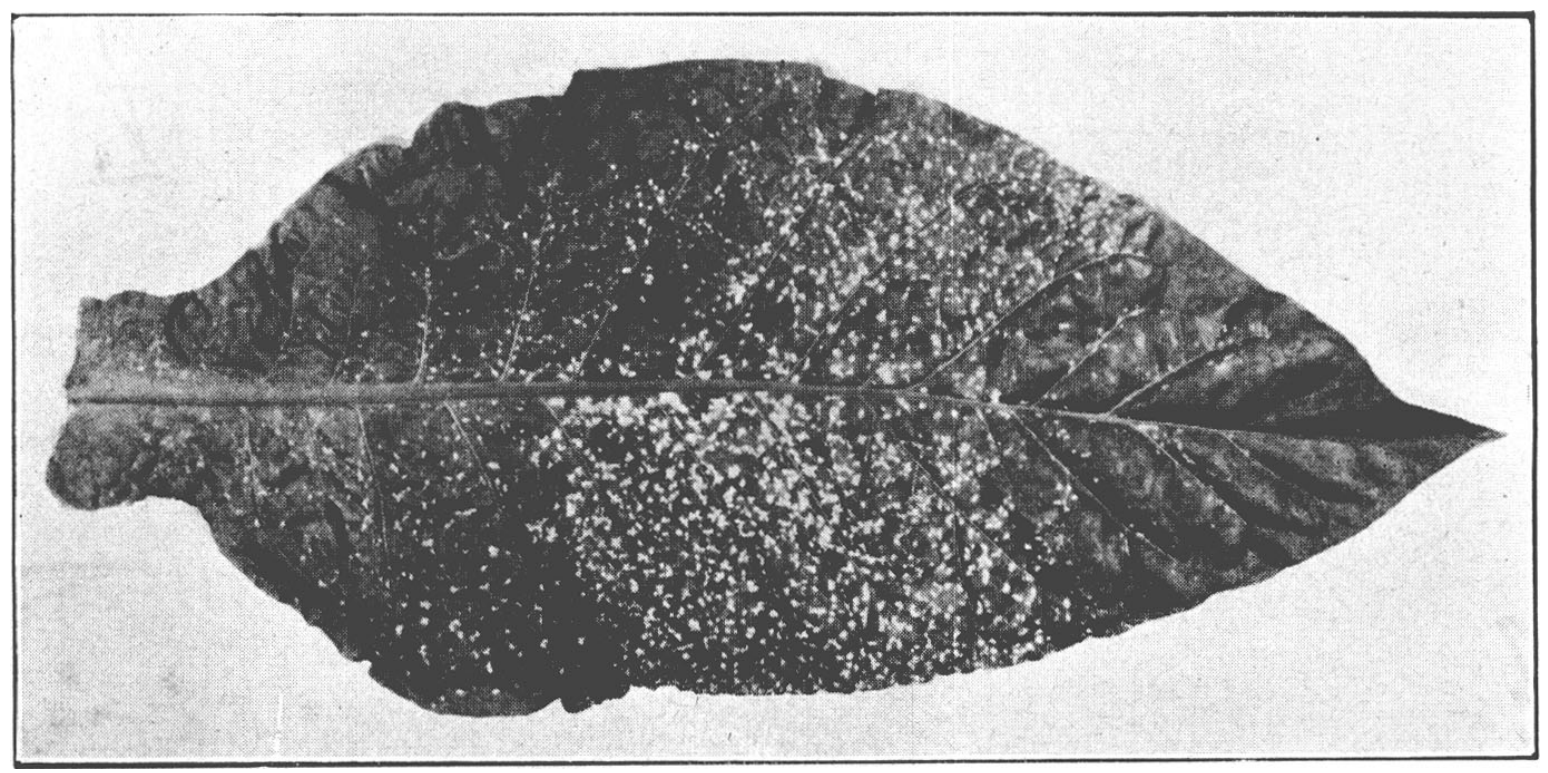

Figura 7 ... Nisolianu labarum var., Sumalra.

(Fôlha de planta afetada, mostrando os sintomas da necrose branca).

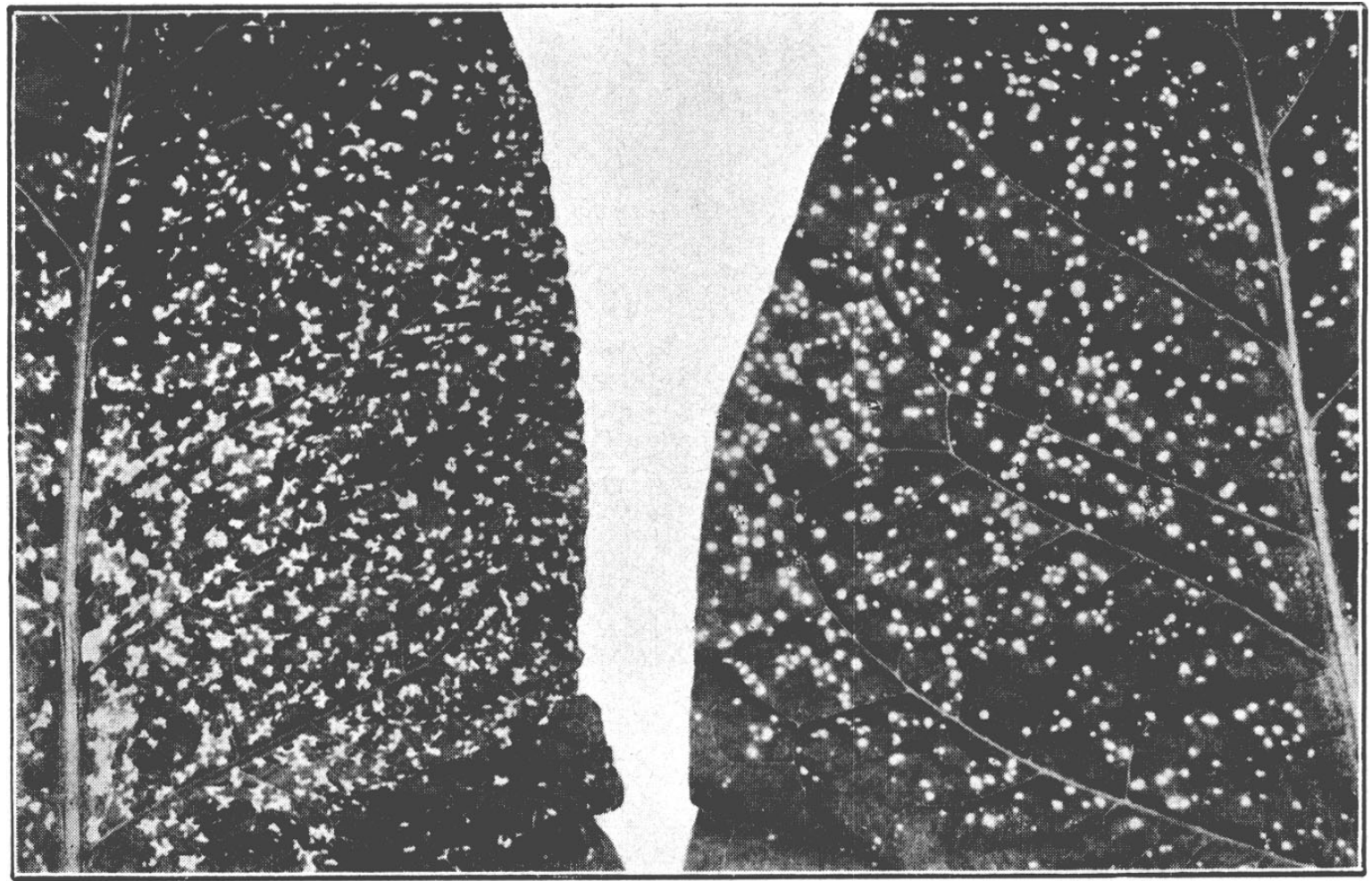

Figura 8 ... Vicoliana lahacum var. Sumatra.

(Fôlhas mostrando os sintomas da necrose branca $(A)$ e das pintas necróticas brancas (B), encontradas em associação com o virus da faixa das nervuras). 
ano em que a experiência foi realizada, não pôde obter dados satisfatórios. Fawcett (8) empregou preparações de derris e sulfato de nicotina no contrôle da corcova do fumo na Argentina, mas os resultados foram negativos. Resultados positivos no contrôle da "corcova" foram obtidos com arseniato de chumbo (11). Fawcett (12) verificou também que o uso do enxofre molhável não deu bons resultados no contrôle da peste negra dos tomates que é causada pelo mesmo virus da "corcova". O uso da căl, à qual se adicionou óleo para espalhar melhor, deu bons resultados. Recentemente. Magee e Morgãn (19) relataram que tinha sido obtido, pela pulverização con tártaro emético, o contrôle dos vetores do virus do "spotted-wilt" na Austrália... Franckliniella in sulari." c Thrip.r tabaci---em plantações de tomates.

O emprêgo de inseticidas pärá o contrôle dos vetores de vira-cabeça na plantação deve ser efetucado, principalmente, durante os primeiros 30 ou 40 dias após a transplantação. Uma vez passada esta época crítica, as plantas'já se acham um tanto desenvolvidas, tendo adquirido certa resistência à moléstia.

Apesar da pouca influência do contrôle do vetor no viveiro, sôbre a manifestação da moléstia em campo, êle deve ser feito, pois, do contrário, arriscar-se-ia à perda de um grande número de mudas, que talvez viessem a faltar para a plantação.

É sempre desaconselhável efetuar a plantação de fumo próximo a flores, tomateiros ou outras plantações de fumo. Vetores cla moléstia, muitas vêzes virulíleros, passam então de tais plantas para o fumo, introduzindo vira-cabeça na plantação.

Outra maneira de controlar a moléstia consiste na escolha de regiões, para o plantio do fumo, onde a incidência de vira-cabeça seja pequena. Bragança, São Bento do Sapucaí, Limeira, etc., são regiões onde a moléstia é menos prevalente do que Campinas, Tietê ou Piracicaba. É claro que outros fatôres têm também que ser levados em conta, como a adaptabilidade do solo da região para o tipo da cultura do fumo que se quer fazer, etc.

Uma das maneiras mais eficientes de controlar vira-cabeça é a escolha da épcca adequada para transplante. Como já dissemos, mesmo na Estação Experimental Central em Campinas, onde a percentagem de plantas afetadas frequentemente se aproxima de $100 \%$, existem épocas de transplante durante as quais a incidência de vira-cabeça é relativamente baixa. Em ensaios efetuados tem sido verificado que as 
épocas mais favoráveis de transplante em relação a vira-cabeça e durante as quais as plantas podem desenvolve\%-se satisfatòriamente coincidem com o início e fim da estação de chuvas. Mudas de fumo transplantadas durante setembro ou outubro, conforme as chuvas comecem, mais cedo ou mais tarde, desenvolvem-se satisfatòriamente e não são muito atacadas por vira-cabeça. Esta época apresenta, todavia, um inconveniente: as plantas vão maturar em época chuvosa $e$ isto pode prejudicar os trabalhos de colheita e preparo do produto. A outra época favorável coincide com os meses de fevereirı ou março. Estas épocas são, contudo, um tanto tardias e há frequentemente falta de chuvas para um crescimento satisfatório das plantas.

\section{A NECROSE BRANCA OU COUVE}

A necrose branca foi tida, a princípio, ccmo uma moléstia diferente da então chamada "couve" ou "fumo couve.". Em estudos efetuados. verificou-se então que "couve" nada mais era que uma fase tardia da moléstia, seguindo-se às manifestações de necrose branca.

Além do fumo, diversas outras espécies de Nicoliana foram infetadas pelo virus causador, em experiências de inoculação. Podemos citar as seguintes:. . rustica,. . angustijolia $\left(^{*}\right), N$. repanda,. . ry/t"evtric, $N$. langsdorfii e N. longijlora. Entre outras Solanacex, mostraramse suscetíveis Solanum nodijlorum e Nicantra physaloides. Uma investigação sistemática do círculo de hospecieiras dêste virus não foi aincia feita, mas seria de muito interêsse que êste trabalho lôsse realizado.

A importância econômica da necrose branca ou "couve" é muito grande nos arredores de Tietê. Neste município, tem mesmo maior importância que vira-cabeça. A percentagem de plantas atacadas é muito elevada, atingindo, às vêzes, perto de $100 \%$. Plantas afetadas nunca morrem em consequência do ataque da moléstia, mas têm a produção diminuída e as fôlhas se tornam de qualidade muito inferior. Para o caso de fumo de estula teriam valor quase nulo.

Além do município de Tietê, esta moléstia já foi constatada em Campinas, Piracicaba, Limeira, Bragança, Iacanga, Itapira, Santa Rita, São Bento, São Carlos, Socorro e Tupí.

(") Não há certeza quanto à posição taxonômica çesta espécie. 


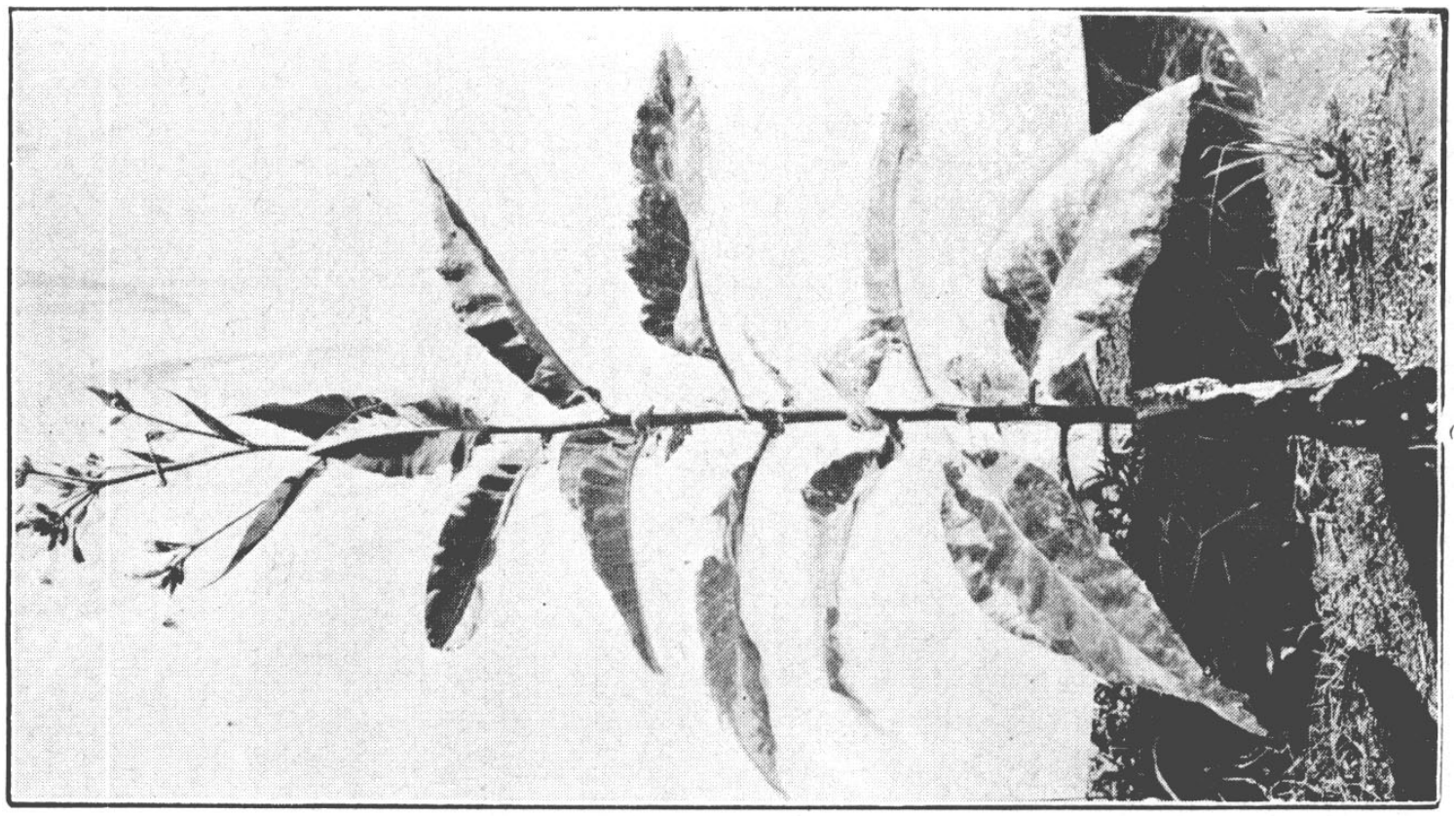

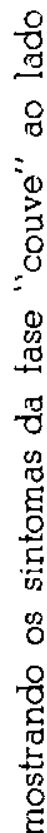

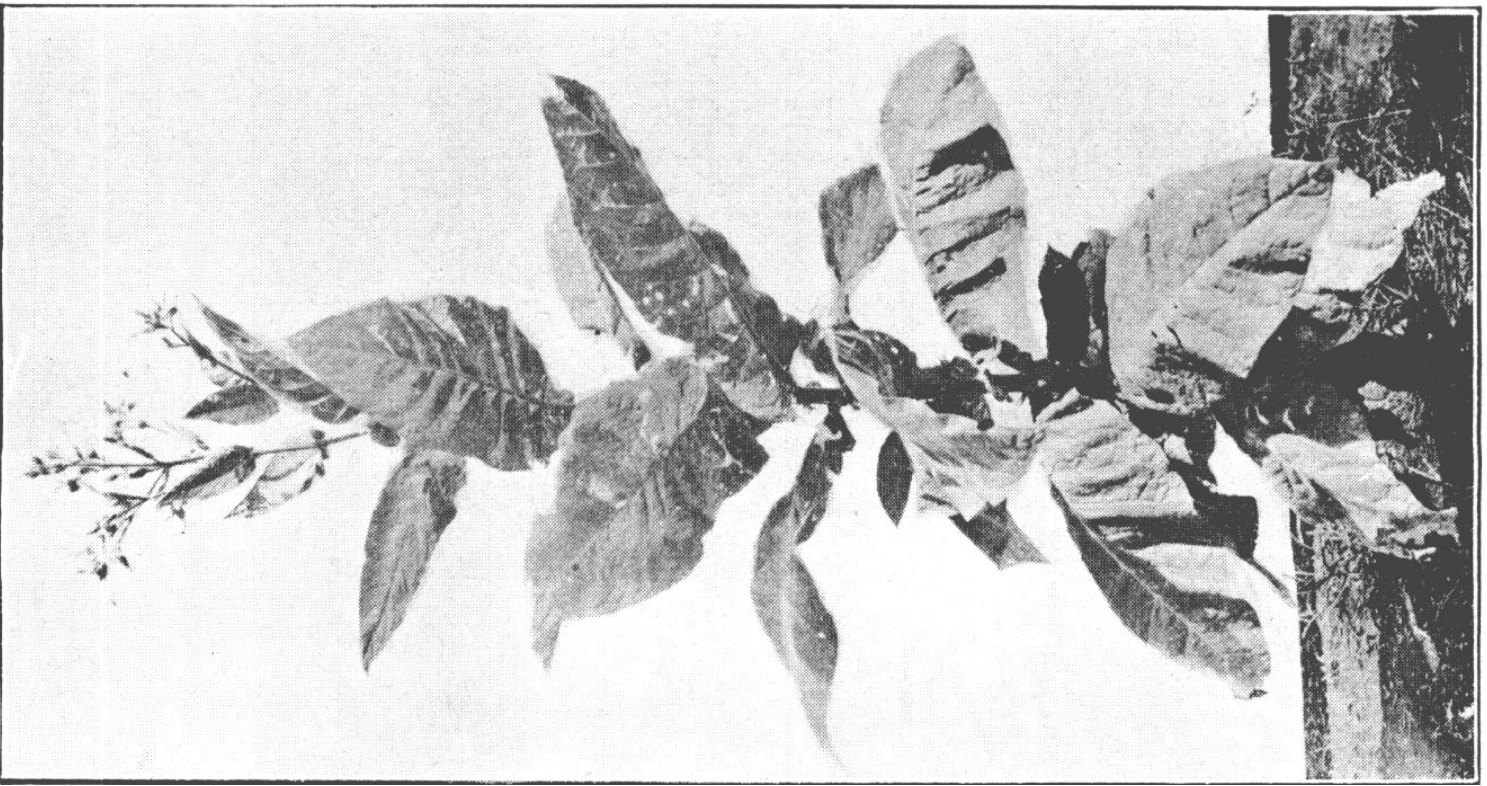

草 


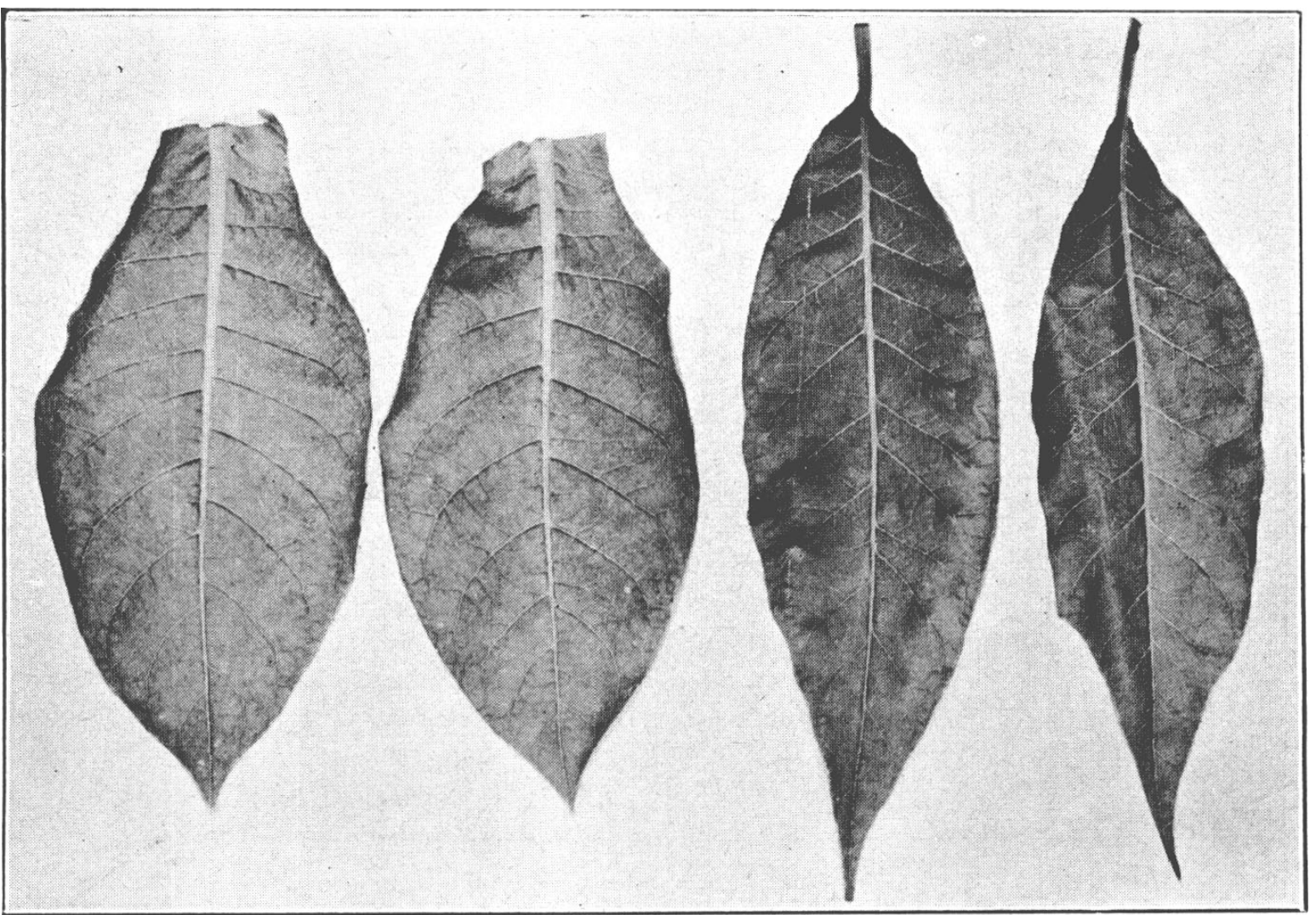

Figura 10 .... Nicotiana tahacum var. Virininia.

(Fôlhas de planta afetada di fase "couve", mostrando os pecíolos em comparação com tôlhàs de planta sadia).

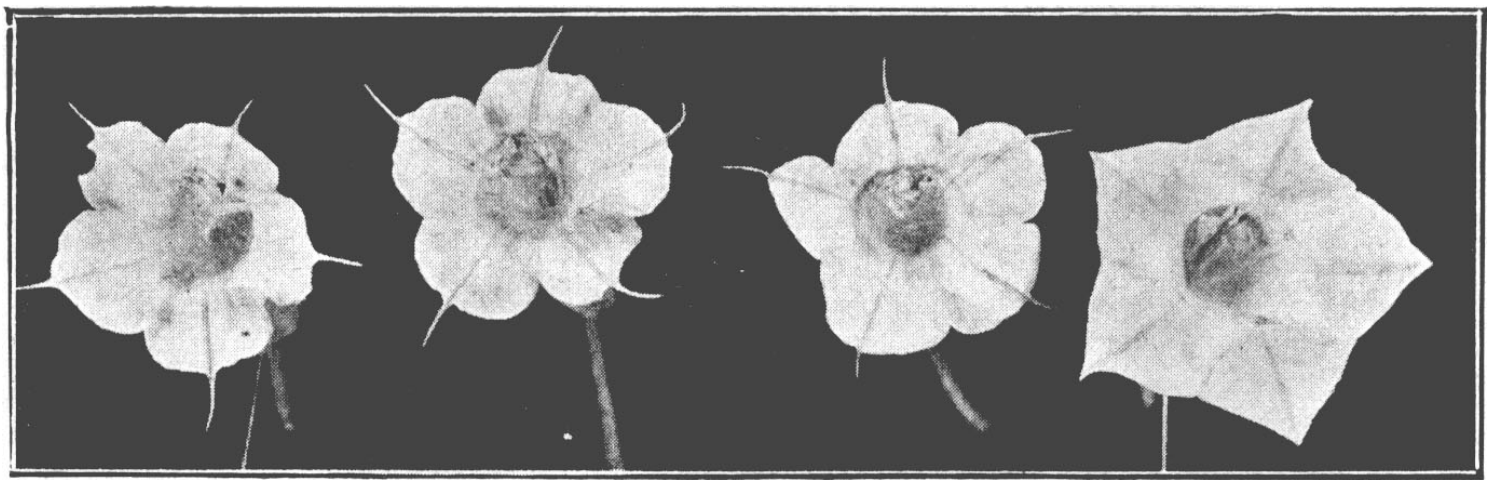

Figura 11 .... Nicotiana labacum var. Firyinia.

(Flores de planta afetada mostrando os apículos das pétalas, ausentess no caso de uma flor de planta sadia direita). 


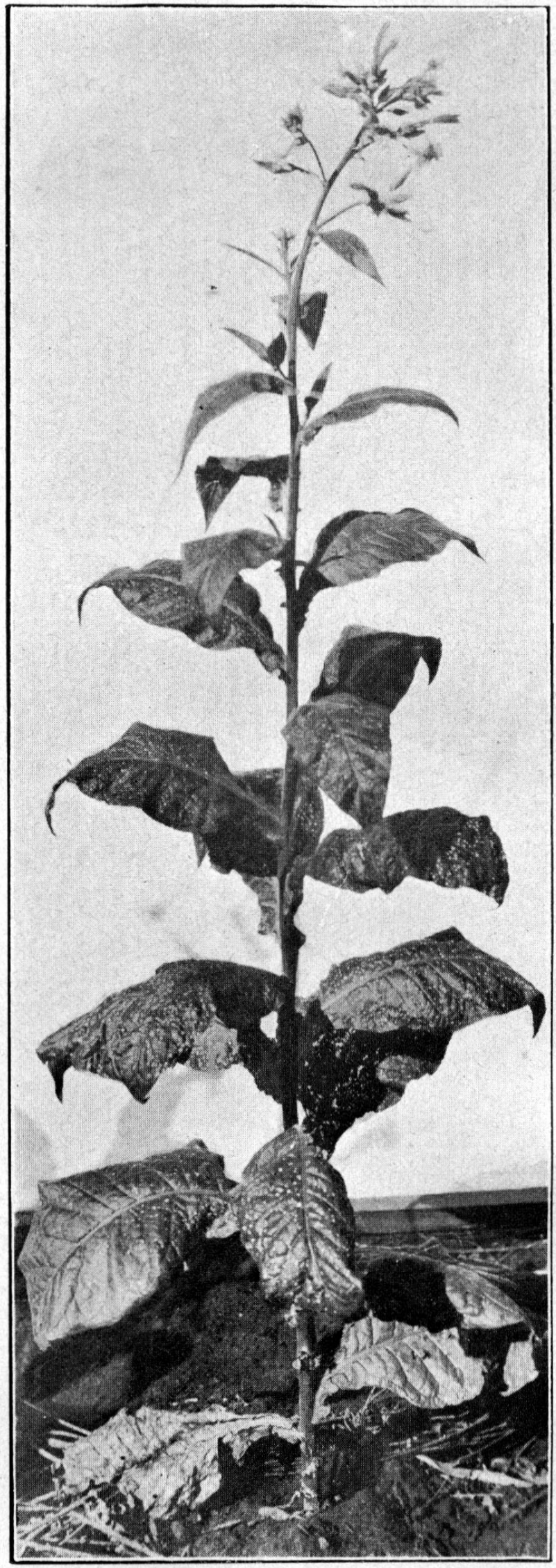

Figura 12 - Nicotiana tabacum var. Sumatra. (Planta afetada pela faixa das nervuras mostrando as pintas necróticas brancas). 


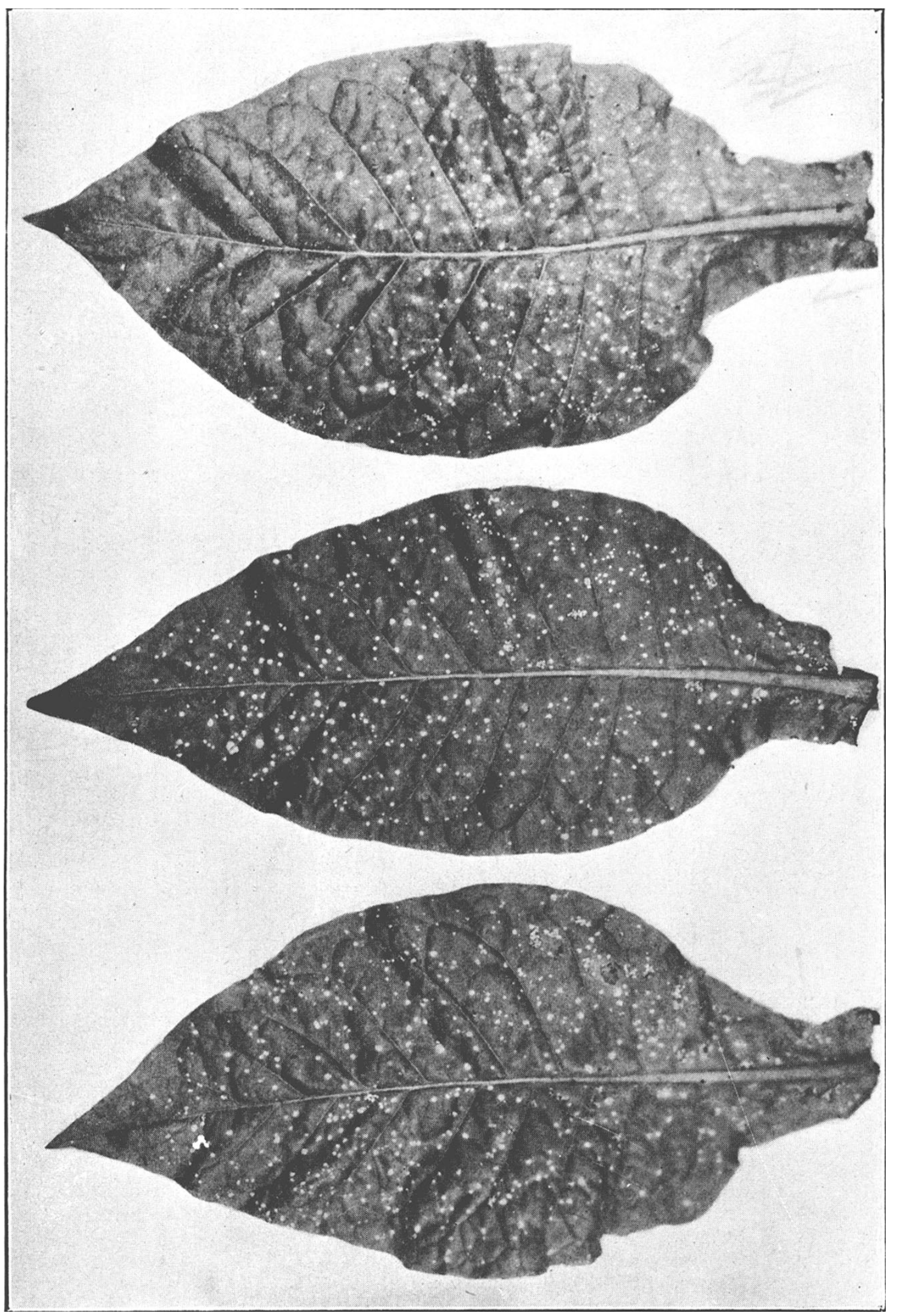

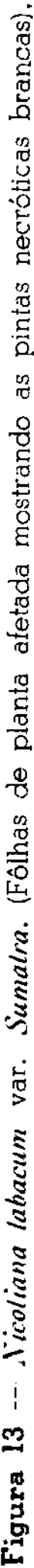




\section{Sintomas}

A necrose branca ou couve é, principalmente, uma moléstia das plantas na plantação. No viveiro é muito raramente observada e quase sempre no caso de mudas passadas que alí ficaram. Na plantação pode-se manifestar em qualquer ocasião, até próximo ao florescimento. Seu aparecimento é, porém, mais comum quando as plantas estão com um a dois meses de transplantadas.

A sintomatologia pode ser dividida em três fases, para maior clareza: a necrose branca, o restabelecimento aparente e a fase "couve".

Necrose branca - As fôlhas novas das plantas afetadas mostram os sintomas de necrose que, de início, pode ter uma aparência um tanto oleosa, só mais tarde se tornando de côr clara. A necrose pode manifestar-se nas ilhotas do parênguima, nas nervuras de terceira ordem ou como linhas quebradas acompanhando as nervuras de primeira ou segunda ordem. As lesões das ilhotas do parênquima podem ter uma forma angular, estrelada, ou, em raros casos, arredondada. Observando-se as lesões necrótica's com um certo aumento, nota-se que elas são deprimidas nas duas faces da fôlha; a parte necrótica tem cêrca de metade da espessura normal da fôlha. Além da necrose, as fôlhas afetadas mostram enrugamento e mais tarde rasgaduras. Isto é consequência do desenvolvimento desigual da superfície da fôlha devido à manifestação da necrose quando estas estavam ainda em crescimento. Necrose tem sido, em çasos raros, observada na parte interna do pecíolo próximo à haste e também na medula da haste. Os sintomas de necrose branca manifestam-se em um número variável de fôlhas, geralmente entre 3 e 10. Na transição da fase necrose branca para restabelecimento aparente, formam-se algumas fôlhas que mostram os sintomas sòmente nas proximidades do ápice.

Restabelecimento aparente - Após a formação de algumas fôlhas com sintomas apenas na proximidade do ápice, desenvolvem-se outras com aparência quase normal. Em seguida, as novas fôlhas começam a mostrar os sintomas da fase "couve".

Fase "couve" - Os sintomas da fase "couve" variam em intensidade, de acôrdo com a severidade da moléstia. Nas primeiras fôlhas que mostram os sintomas de "couve", êstes não são muito acentuados, mas tendem a se acentuar nas fôlhas que aparecem depois; em geral, são mats típicos nas fôlhas médias e superiores da planta. A manifes- 
tação dos sintomas de "couve" depende tămbèm da ocasião em que a planta mostrou necrose branca. Aparentemente, quanto mais cedo esta ocorrer, tanto mais acentuados serão os sintomas de "couve", dependendo, como já foi dito, em parte, da severidade da moléstia. Plantas afetadas tardiamente geralmente näo mostram os sintomas de "couve", pois não há tempo necessário para a evolução dos sintomas. O ângulo de inserção das fôlhas "couve" é um tanto altelado para maior ou menor; as fôlhas tornam-se mais duras e espêssas; a superfície torna-se mais lisa, perdendo um pouco o "grão"; as fôlhâs podem-se tornar um tanto acanaladas e as margens podem-se curvar parc a parte inferior; muitas fôlhas mostram as margens dentadas ou crenadas, quando, normalmente, são lisas; há uma tendência para sé tornarem mais estreitas e no caso de algumas variedades de fôlhas sésseis, estas se tornam pecioladas. Êste é o caso das variedades Virginia Bright, Amarelinho. Sumatra, etc. Esta transtormação de fôlhas sésseis em pecioladas é que originou o nome "couve". As flores mostram sintomas um tanto peculiares: a corola que, normalmente, é tubular pode apresentar-se formada de pétalas separadas. Como regra geral, a forma do limbo das pétalas é modificada, havendo a formação de um apículo na extremidade superior.

A formação de fôlhas pecioladas em variedades de fôlhas sésseis e a presença de apículos na corola, constituəm os melhores sintomas para identificação da moléstia.

Nas plantas "couves" nem sempre foi possível a observação de fôlhas com necrose branca. Isto resultou quase sempre do fato de que as fôlhas que tinham necrose branca eram as mais inferiores, tendo-se tornado sêcas e desprendido da planta.

\section{Etiologia}

O virus causador de necrose branca ou "couve" é, provàvelmente, - mesmo que causa a moléstia "tobacco streak" nos Estados Unidos (Annulus oræ H.) (16).

O virus da necrose branca ou "couve" pode ser transmitido mecânicamente, mas com alguma dificuldade. Na transmissão da moléstia sob condições naturais, a transmissão mecânica não desempenha nenhum papel. A disseminação desta moléstia deve-se dar, com tôda certeza, por meio de algum inseto vetor. A descoberta dêste seria de grande importância e, possivelmente, viria facilitar a formulação de medidas de contrôle. 


\section{Contrôle}

O desconhecimento do vetor dificuita a aplicaçäo de medias que visem o seu contrôle. É, for'́m, possivel que ensaios com civersos inseticidas conseguissem lançar alguma iuz sôbre essa questão. Tencionamos oportunamente experimentar nicotine, rotenona e civersos outros inseticidas que têm ação sôbre os insetos sugadores, no contrôle desta moléstia.

Não são conhecidas variecicdes resistentes à necrose branca ou "couve" ; há diferenças em suscetibilidade, mas mesmo aquelas menos suscetíveis não apresentam resistência satistatória.

A escolha da época de plantio oferece alguma possibijidade para o contrôle da moléstia. Ela tem sido observada, princicalmente, nos meses quentes e úmidos do ano, como dezembro e janeiro.

\section{A FAIXA DAS NERVURAS}

Esta moléstia tem sido observada sòmente nas localidades de São Paulo (17), Campinas e Tupí. Na Estação Experimental Central de Campinas pôde adquirir bastante importância econômica, sendo geral. mente elevado o número de plantas atacadas. A faixa das nervuras não é uma moléstia sòmente do fumo. O mesmo virus ou um virus muito semelhante a êste é mais comum em plantações de batata, nas quais causa uma moléstia de grande importância. A sua ocorrência em plantações de fumo já foi verificada também em outros países (15). Em experiências realizadas, as seguintes espécies mostraram-se suscetíveis ao mesmo virus: Nicotiana rustica, $N$. vyluestris, $N$. langsdoriii, $N$. glutinosa, $N$. repanda, $N$. longiflora, $N$. quadrivalvis, $N$. digluta, $N$. angurtijolia $\left(^{*}\right), N$. Gossey, $N$. sander $x, N$. nudicauli, e.$V$ paniculala. Além destas espécies de Nicotiana, Lycopericon esculenlum, I. pimpinellifolium e Cyphomandra betacea são também susceníveis.

Os danos causados pela faixa das nervuras são relativamente ligeiros para certas variedades. Podem mesmo passar despercebidos a um exame superficial. A produção é um tanto diminuída e a qualidade das fôlhas um pouco prejudicada. Para o caso das variedades do grupo Sumatra, usadas para produção de capas de charuto, já os danos causados são maiores. As plantas desta variedade, quando atacadas, mostram uma reação necrótica caraterizada pelo aparəcimento de pintas brancas arredondadas.

(') Não há certeza quanto à posição taxonômica desta espécie. 


\section{Sintomas}

Esta moléstia manifesta-se comumente na plantação, sendo rara em viveiro. É principalmente durante a segunda metade do ciclo da vida que as plantas se mostram afetadas.

A primeira manifestação da moléstia é a Jalidez das nervuras das fôlhas novas. As fôlhas mais tarde formadas mostram manchas cloró. ticas arredondadas nas ilhotas do parênquime. Estas manchas só são visíveis depois que elas atingem um certo cesenvolvimento. $\grave{A}$ proporção que as fôlhas com manchas cloróticas aumentam em tamanho, as áreas cloróticas crescem, tomando conta de tôda a superfície entre as nervuras de terceira ordem e respeitando sòmente pequenas áreas paralelas a estas. Dá-se então a formação das faixas das nervuras, que são mais ou menos contínuas. Em muitas plintas, as áreas cloróticas não se transformam, permanecendo arredondadas. Além do tipo descrito, há um outro tipo de faixa das nervuras, presente nas plantas atacadas. Neste, as faixas são de côr verde mais escura do que a normai e apresentam-se interrompidas. De maneira geral, pode-se dizer que as manchas cloróticas são mais conspícuas nas fôlhas das plantas em desenvolvimento vegetativo rápido, ao passo que as faixas das nervuras são mais comuns em fôlhas completamente clesenvolvidas. Em certos casos, as faixas das nervuras são visíveis sòmente na parte da fôlha próxima ao pecíolo. À medida que as plantas envelhecem há uma di. minuição na intensidade dos sintomas. Certas variedades de fumo mostram sintomas fracos e indistintos quando atacàdas. Tal é, por exemplo, - caso das variedades Kentucky e Amarelinho. Em adição ao que foj. atrás descrito, as variedades do grupo Sumatra e algumas do grupo Turkish mostram nas fôlhas a presença de lessões necróticas brancas, arredondadas. Estas são fáceis de distinguir dos sintomas da necrose branca (Fig. 8).

\section{Etiologia}

O virus causador da faixa das nervuras pertence ao grupo do virus $\mathbf{Y}$ da batatinha (Marmor cucumeris var. Upsilon). É fàcilmente trans. missível por inoculação mecânica. É de se crer, porém, que na natureza a transmissão mecânica não desempente papel algum na disseminação do virus em plantações de fumo. Êste é comumente disseminado por atídeos. O vetor ou vetores sob as nossas condições ainda não são conhecidos. 

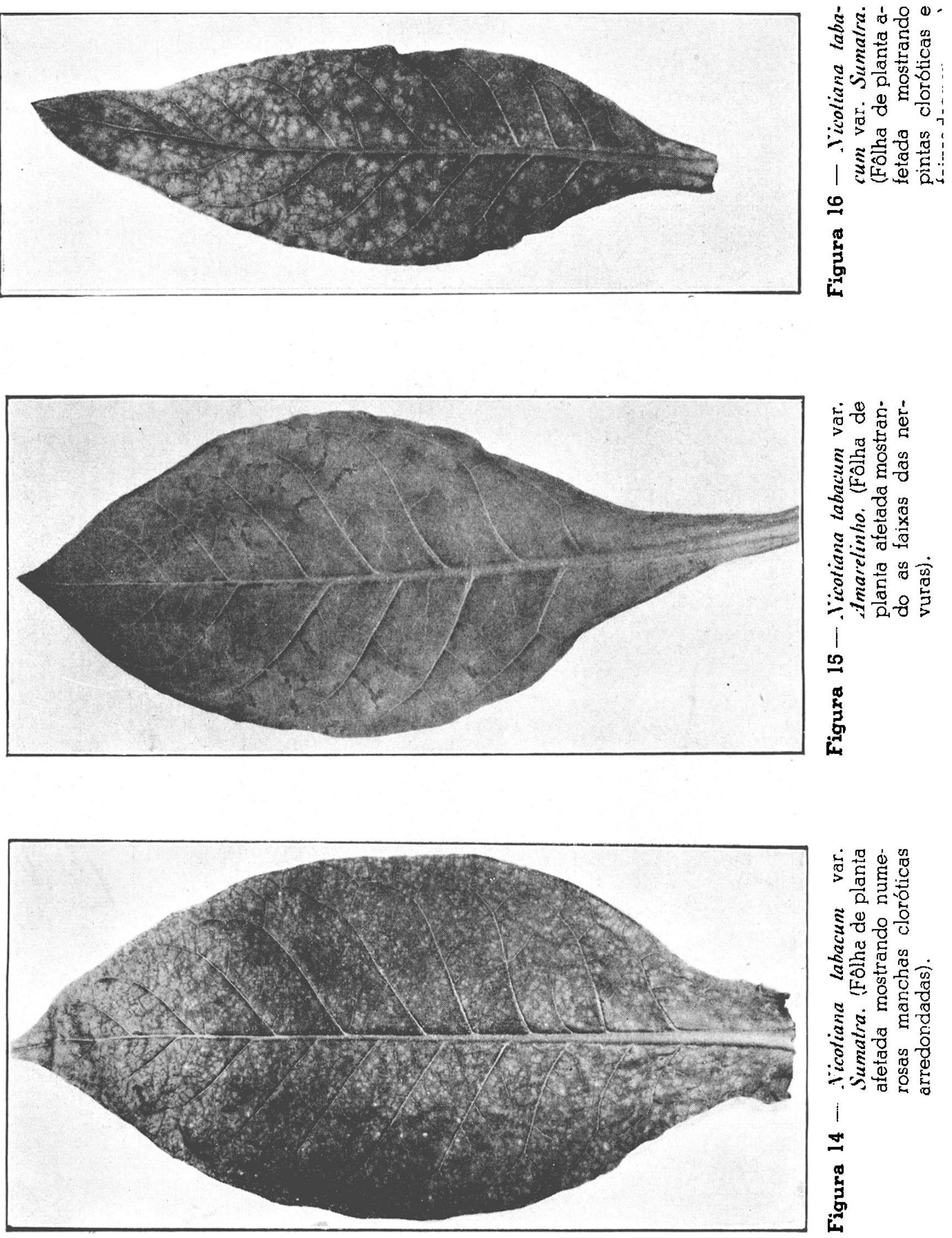

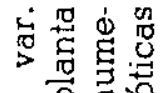
름 ะับㅇํㅇ 记

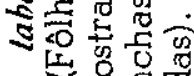
ะ . จำ

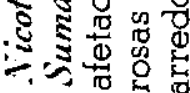
品 


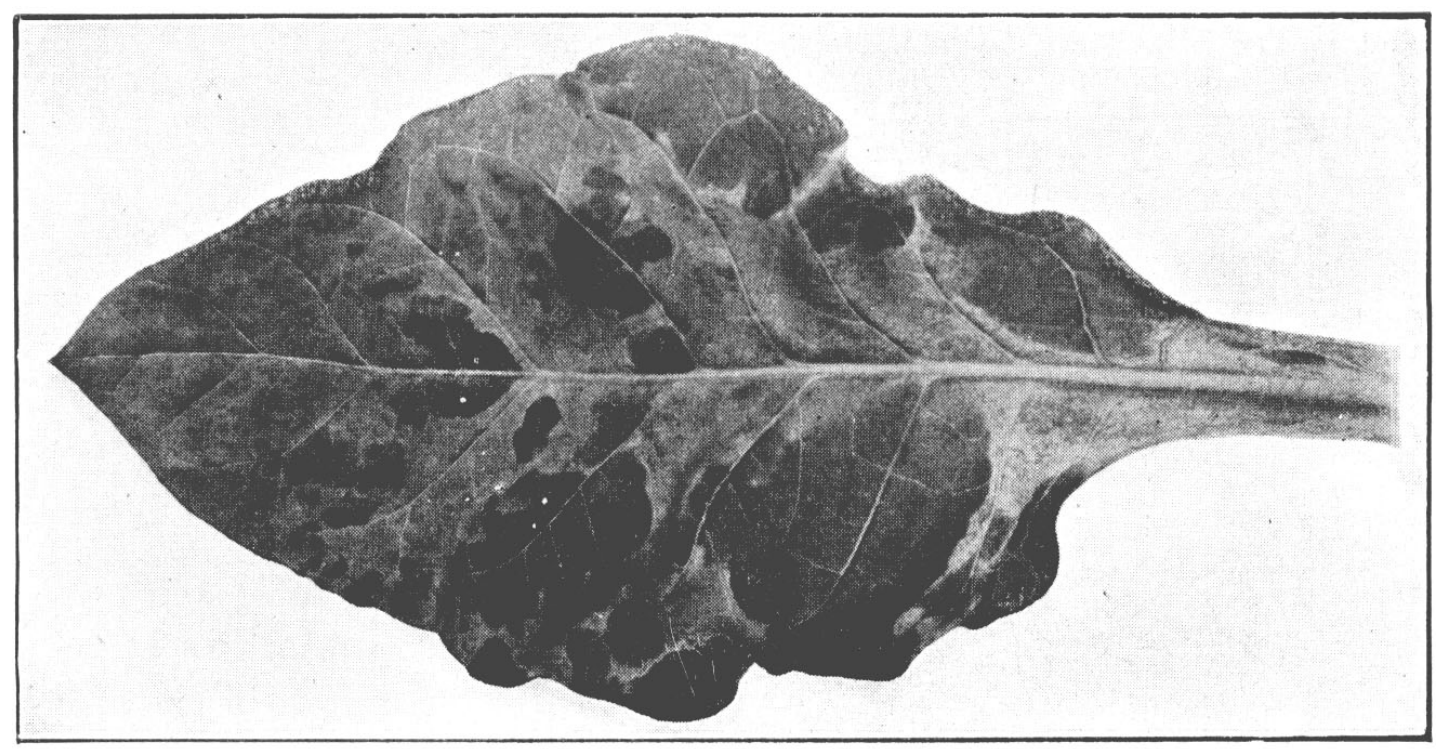

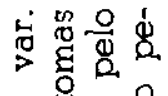

동ㅇㅇㅇ

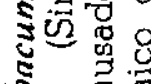

ह 500

.

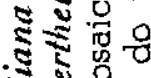

: ¿

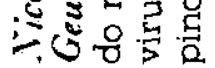

占

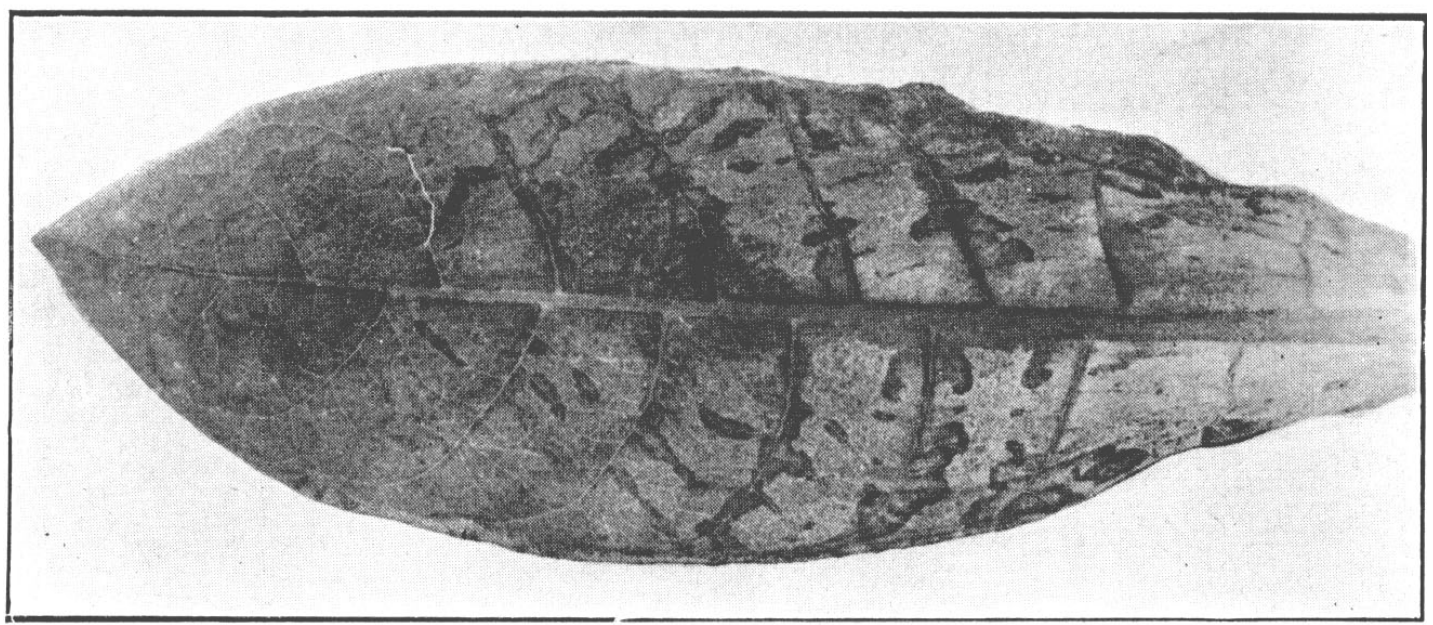

要 
A fonte de inóculo do virus das faixas das nervuras, de onde o virus passa para o fumo, também não é conhecida. É possível que isto se dê, a partir de plantas doentes de batata ou, então, de hervas da. ninhas suscetíveis.

\section{Contrôle}

A eliminação das fontes de inóculo é a medida mais aconselhável. Assim, será de vantagem evitar a plantação de fumo perto de plantações de batata. Algumas Solanaceæ nativas do gênero Solanum podem ter o virus. Julgamos, no entanto, que a não ser em casos especiais, esta moléstia não atingirá grandes proporções, não se justificando, portanto, medidas especiais de contrôle. A destruição dos vetores, provàvelmente afídeos, oferece uma outra possibilidade de contrôle.

\section{OS MOSAICOS}

É comum observarem-se, nas plantações de fumo, plantas cujas fôlhas apresentam áreas verde-claras, ao lado de área verde-normais ou verde-escuras, geralmente acompanhadas de rugosidade e malformação. Estas fôlhas mostram então o que se denomina mosaico.

Duas formas de mosaico do fumo são encontradas em São Paulo. O mosaico causado pelo virus do mosaico comum do fumo (Marmor tabaci $\mathrm{H}$. var. sulgare $\mathrm{H}$.) e o mosaico causado pelo virus do mosaico do pepino (Marmor cucumeris $H$. var. rulgare $H$.). Não é possível separar estas duas moléstias sòmente pela observação dos sintomas, pois êstes são muito semelhantes. Para que sejam identificados os virus causadores, torna-se necessário efetuar testes de inoculação em plantas apropriadas.

Mosaico comum : É encontrado em qualquer plantação de fumo em maior ou menor percentagem. Sua incidência é bastarite alta nas lavouras de particulares e baixa nas estações experimentais. 0 mosaico comum manifesta-se nas sementeiras e nas plantações.

As fontes de inóculo para as sementeiras podem ser diversas. Restos de cultura não devem ser aproveitados como adubo para os canteiros, pois podem conter o virus; as pessoas que fumam podem ter as suas mãos contaminadas e infetar as plantas durante os tratamentos feitos no viveiro. $O$ cigarro de papel não apresenta tanto perigo em contaminar as mãos dos fumantes, mas as pessoas que usam fumo de: 
corda não devem preparar cigarros quando estão trabalhando com as mudas de fumo. Plantas da família Solanaceæ, crescendo nas proximidades dos canteiros, podem também servir de fonte de inóculo. Já foram observadas plantas adultas de fumo afetadas pelo mosaico comum em diversas fazendas, crescendo dentro de cercados onde estavam sendo formadas as mudas.

$\mathrm{Na}$ plantação, as fontes de inóculo podem ser as mesmas já citadas para as sementeiras. Além disso, há a considerar as soqueiras do ano anterior, pois estas se mostram frequentemente afetadas pelo mosaico comum. Plantas afetadas, levadas das sementeiras, representam também uma importante fonte de virus neste caso.

O mosaico comum é uma moléstia altamente infecciosa. No início da cultura poucas são as plantas afetadas, mas o número destas aumenta consideràvelmente com o avançar em idade da plantação. A disseminação do mosaico comum na plantação e no viveiro dá-se principalmente pelos meios mecânicos, a saber: pelas ferramentas agrícolas, pelas mãos dos operários que efetuam os trabalhos de transplante, desbrota, capação, etc. As ferramentas agrícolas que esbarram numa planta doente e depois numa sadia podem infetar esta última. $\bigcirc$ mesmo se dá com as mãos dos operários, etc. $\bigcirc$ fato de que basta tocar-se numa planta doente e depois numa sadia para se ter transmissão da moléstia, deve ser sempre levado em conta.

\section{Sintomas}

Os sintomas do mosaico comum constam, como já dissemos, de áreas verde-claras ao lado de áreas verde-normais ou verde-escuras. Estas são mais raras e, quando presentes, se manifestam como faixa das nervuras ou em áreas elevadas da superfície da fôlha de conformação arredondada e também denominadas bôlhas. Malformação e rugosidade são frequentes, dependendo a intensidade dêstes sintomas do estado vegetativo da planta, estirpe do virus, etc.

\section{Contrôle}

É aconselhável que os operários evitem o uso do cigarro ou qualquer outra forma de fumo na ocasião em que fazem a transplantação ou executam qualquer outro serviço com as plantas de fumo, seja na sementeira, seja na plantação. Antes de iniciar qualquer trabalho, é vantajoso que as mãos seiam lavadas cuidadosamente com áqua e sabão. 
Ca: $: 0$ o lavrador ou operário toque numa planta afetada deve lavar as mòss novamente antes de prossequir no serviço.

A eliminaçẽo das fontes de inóculo é também aconselhável. Nunca se leve usar restos de fumo como adubo. As hervas más da família Solanacex devem ser erradicadas das proximidades dos canteiros e cáa plantações, assim também como as soqueiras de fumo. Nunca transplazitar plantas doentes para a plantação.

Mosaico do pepino : $O$ mosaico do pepino manifesta-se de preferćncia na plantação. Ataca numerosas outrás plantas, pertencentes a diversas famílias. Não sabemos ainda quais são as plantas que servem de fonte de inóculo para as plantações de fumo sob as nossas condições, e também desconhecemos qual é o vetor ou vetores que aquí disseminam êsie tipo de mosaico. É também transmitido mecânicamente sob condições artificiais, mas a disseminação natural da moléstia se dá, principalmente, por meio dos insetos.

A presença do mosaico do pepino em plantações de fumo não é muito comum, mas já foi verificada em outros países. Em São Paulo, - mosaico do pepino não é de ocorrência tão generalizada em plan. tações de fumo como o mosaico comum. Na Estação Experimental Cen. tral em Campinas, dá-se, porém, um fato curioso: o mosaico do pepino é mais prevalente do que o mosaico çomum. Nas plantações particulares occrre fato contrário. Que o mosaico do pepino é mais prevalente do que o mosaico comum na Estação Experimental Central em Campinas, foi verificado em dois anos seguidos em diversos ensaios de época de transplante. Para a determinação relativa dos dois tipos, amostras de numerosas plantas afetadas foram colhidas em campo, trazidas para laboratório e inoculadas em plantas-testes apropriadas. Em 1939, a proporção encontrada foi de 10 e $90 \%$ para o mosaico comum e mosaico do pepino e no ano de 1940 foi de 3 e 97\%, respectivamente.

\section{Sintomas}

Como já dissemos, não é possível separar o mosaico comum do mosaico do pepino numa base sintomatológica. Os sintomas são idênticos. Observa-se, porém, que nos casos do mosaico do pepino há menos tendência para formação de faixas das nervuras e as áreas verdeclaras ou verde-escuras são maiores. Nota-se também que as áreas cloróticas apresentam um aspecto caraterístico, perdendo ceu brilho e mostrando-se com um aspecto embaçado. Muitas vêzes tôda a su. 
perfície da fôlha mostra êste aspecto embaçado. havendo apenas algumas áreas pequenas de côr verde-escura. Malfcrmação e estreitamento da fôlha são também sintomas frequentes.

\section{Contrôle}

O contrôle do vetor da moléstia e a destruiçăo das fontes de inóculo são as medidas aconselháveis neste caso. Como, porém, não se pode diferenciar o mosaico do pepino do mosaico comun, é conveniente aplicar as medidas aconselhadas para o mosaico comurn para tôdas as plantas com mosaico, indistintamente.

\section{ENCARQUILHAMENTO DA FÔLHA}

Não existe certeza sôbre se esta moléstia é causada por um virus. Devido à grande semelhança entre a sintomatclogia aquí observada e a da moléstia conhecida na África como "leaf-curl", causada pelo virus Ruga tabaci $\mathrm{H}$., preferimos incluí-la neste grupo, a título de tentativa.

Até agora o encarquilhamento da fôlha foi observado sòmente em variedades cultivadas de fumo e em Vicotiana sylvestris, sob as nossas condições. Dados sôbre a resistência das diferentes variedades não são conhecidos. A sua ocorrência já foi notada nos raunicípios de Bragança, Tietê, Limeira, Campinas e Piracicaba.

A importância do encarquilhamento da fôlha é pequena. A per'centagem das plantas atacadas é baixa, mas, quanto à qualidade, as fôlhas ficam bastante prejudicadas. Duas formas de encarquilhamento da fôlha têm sido observadas: a forma rugosa $e$ a forma enrolamento.

Forma rugosa : É a mais comum; marifesta-se em plantas de qualquer idade, na plantação, sendo rara no viveiro. As plantas afe. tadas sofrem uma redução no porte, tanto maior quanto mais cedo forem afetadas; quando afetada muito cedo, a planta permanece com um porte anão. As fôlhas das plantas afetadas exibem os sintomas mais típicos da moléstia: o ângulo formado $\mathrm{com}$ a parte superior da haste torna-se maior do que em plantas sadias; o limbo da fôlha, às vêzes, curva-se para a face dorsal: o comprimento da fôlha é reduzido; a rugosidade manifesta-se sob uma forma açentuada. Observando-se as fôlhas pela sua face ventral, percebe-se que o c.specto rugoso $\epsilon$ devido ao fato de as nervuras serem deprimidas nesta face, e os tecidos situados entre as nervuras de terceira ordem serem salientes e ligeiramente con- 


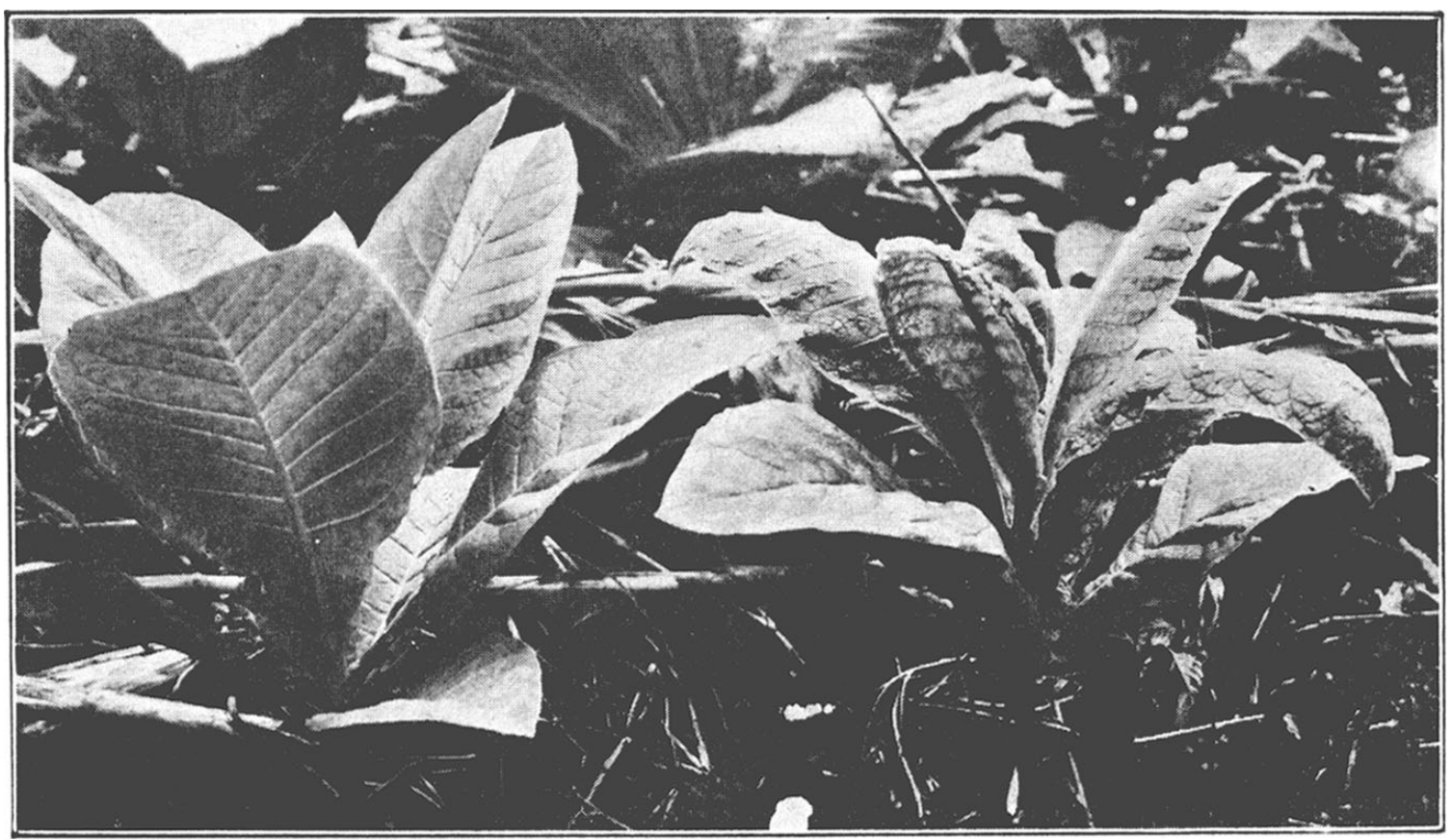

Figura 19 .. Nicotiana labacum var. Amarelinho.

(Planta afetada pela forma rugosa ao lado de uma planta sadia).

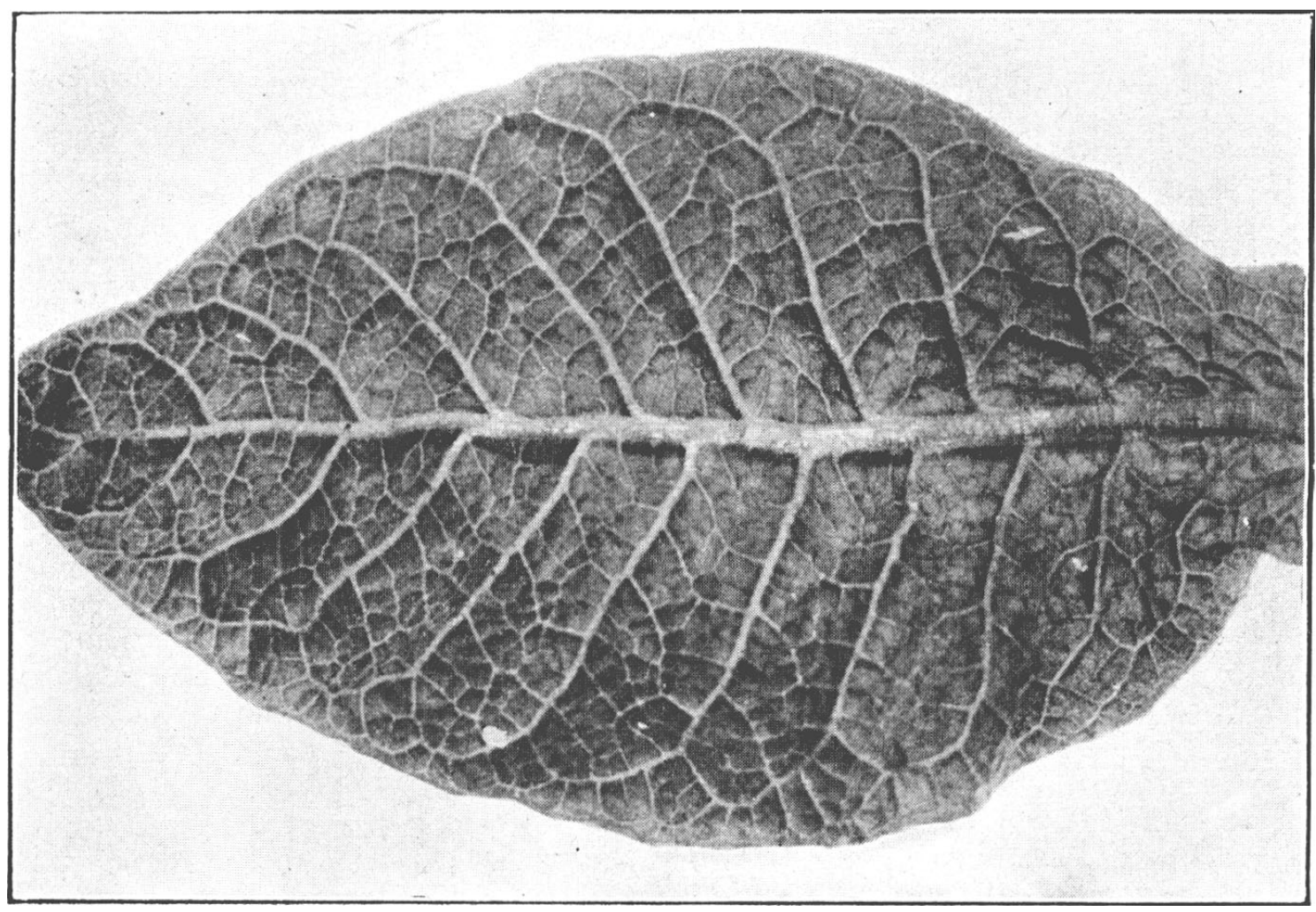

Figura 20 .... Nicotiana labacum var. Amarelinho.

(Fôlha de planta afelada. - Notar as nervuras mais salientes e "tortuosas). 


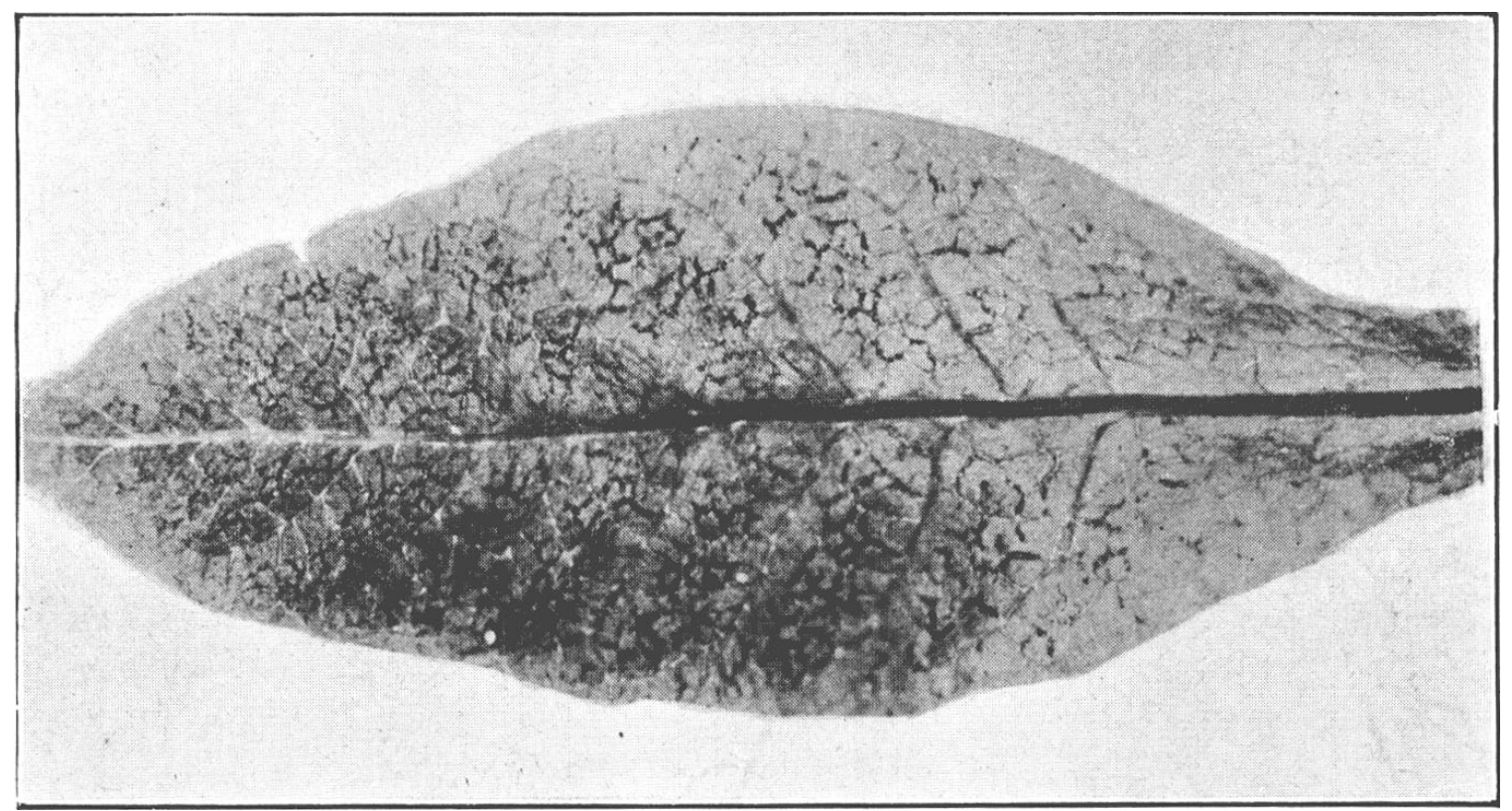

Figura 21 ... Nicotiana labacum var. Creoula. (Fôlha des uma planta afetada pela forma rugosa. Nolar certos comprimentos das nervuras de uma côr verde escura. Fotogralia tirada por transparência).

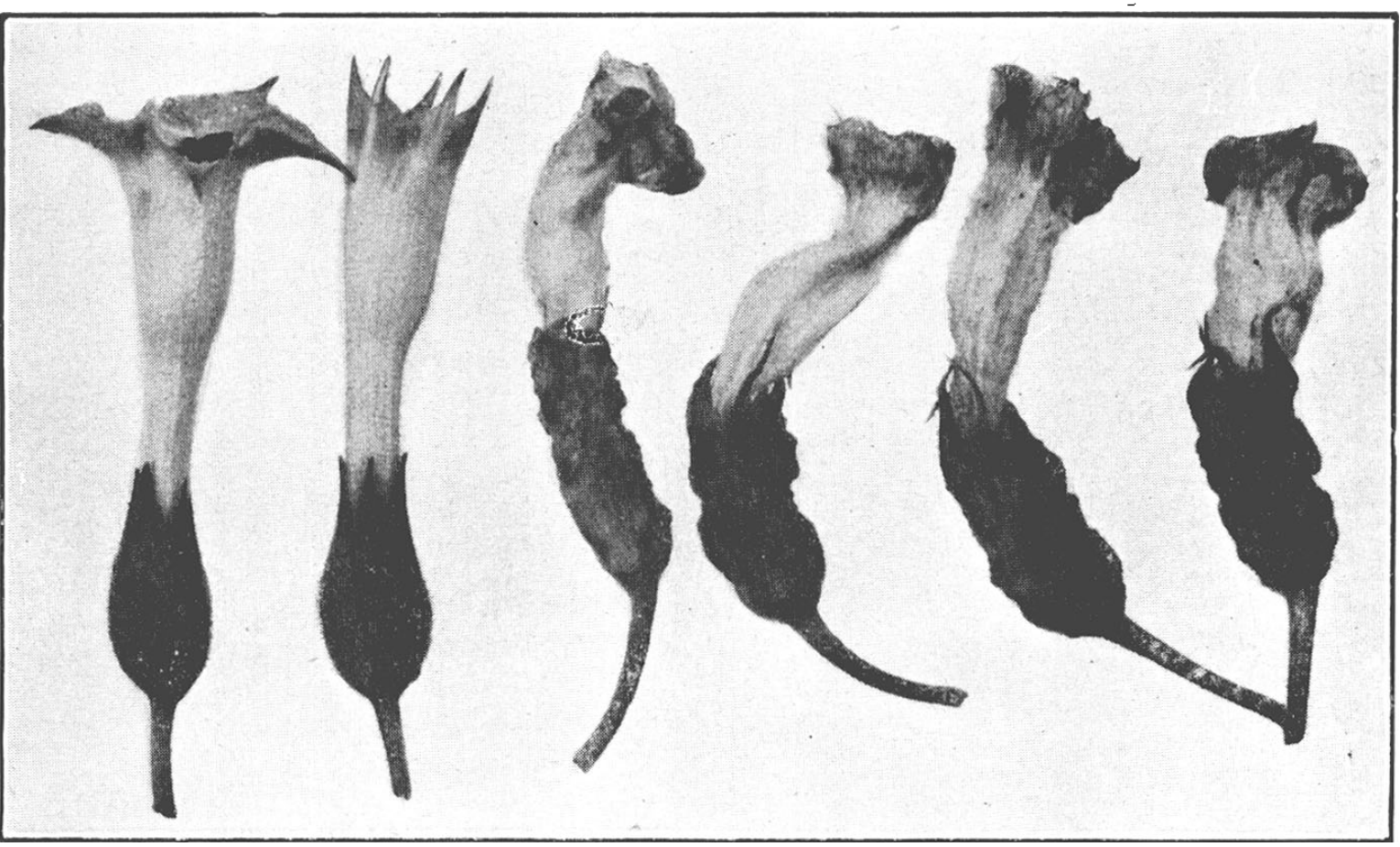

Figura 22 . Vicoliana labacum vai. Imaretinho. (Flores de planta atetada do lado de flores de planta sadial. 


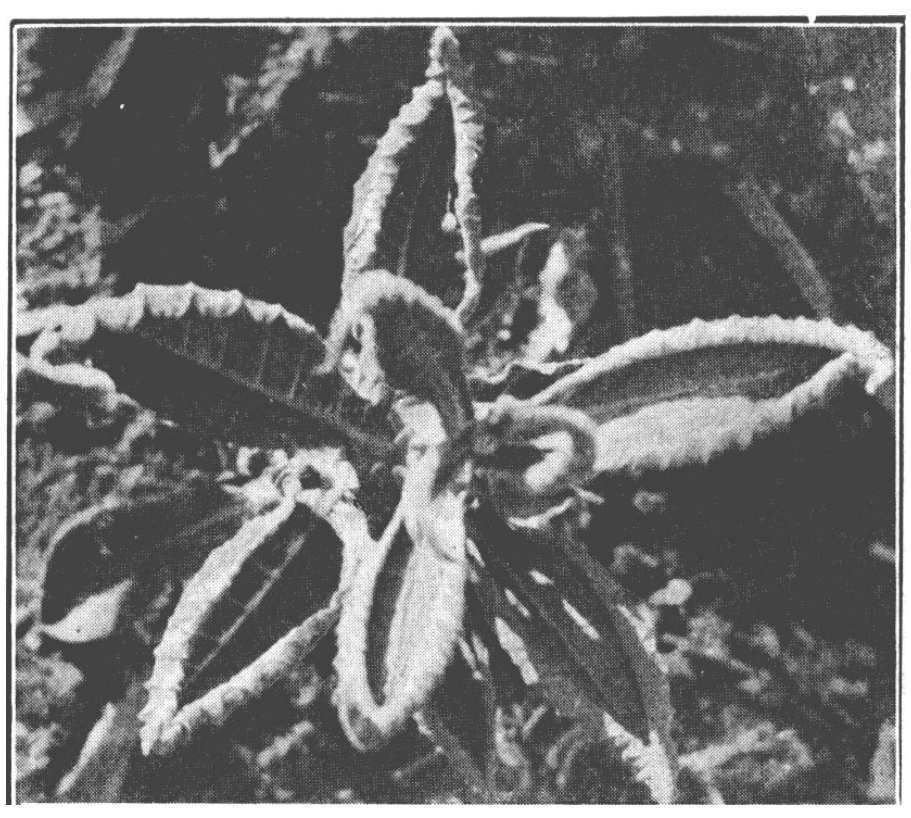

$\stackrel{0}{3}$

范芯焉

ฐष

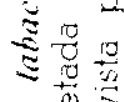

$\approx \stackrel{0}{\square}>$

$\approx$

焉要

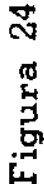

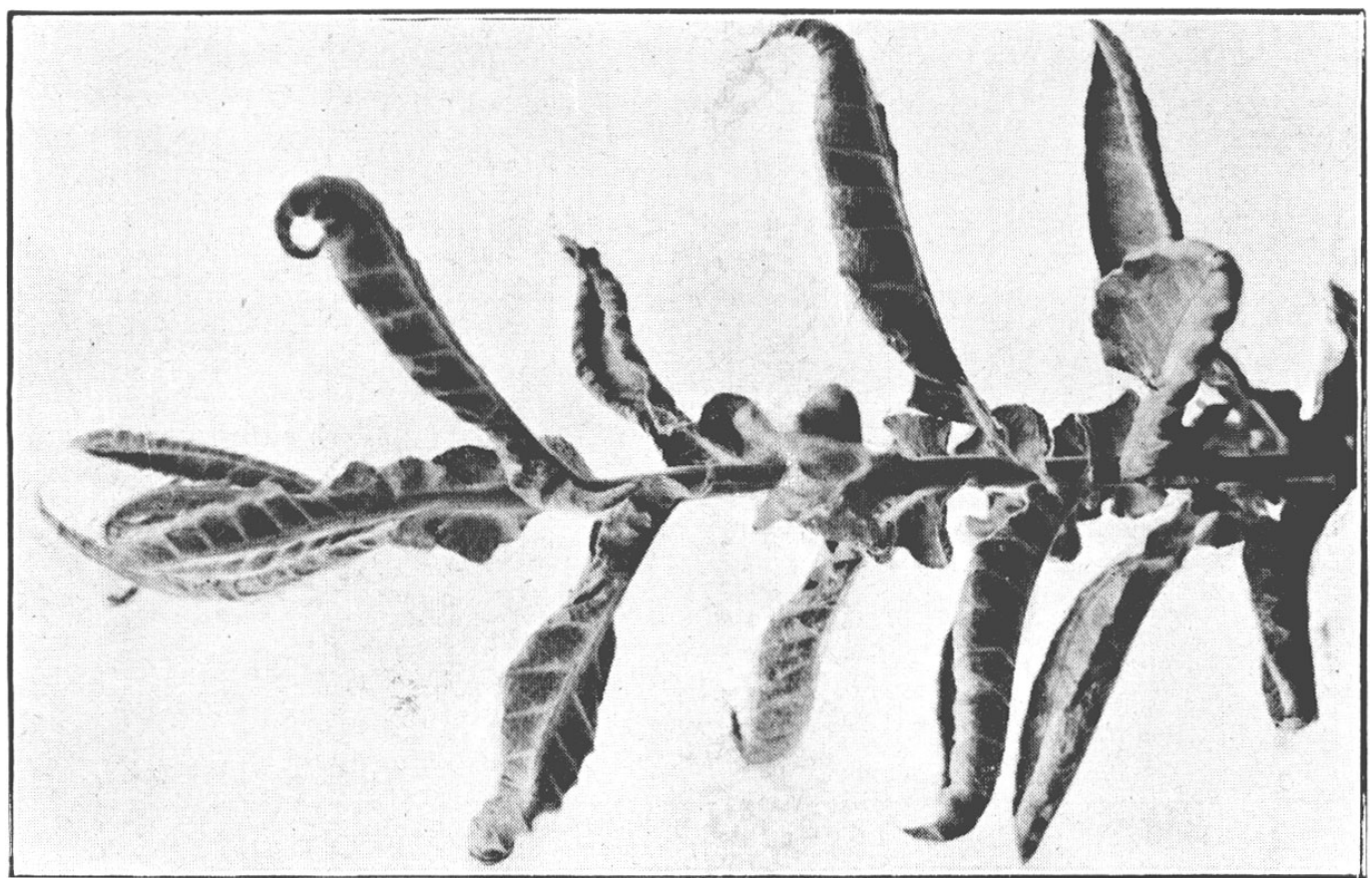

$\approx 0$

$\therefore$

的空

$\approx \frac{10}{10}$

इ

$\approx$

$\Xi \underset{0}{0}$

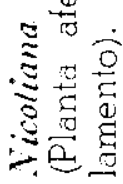

m

苟 


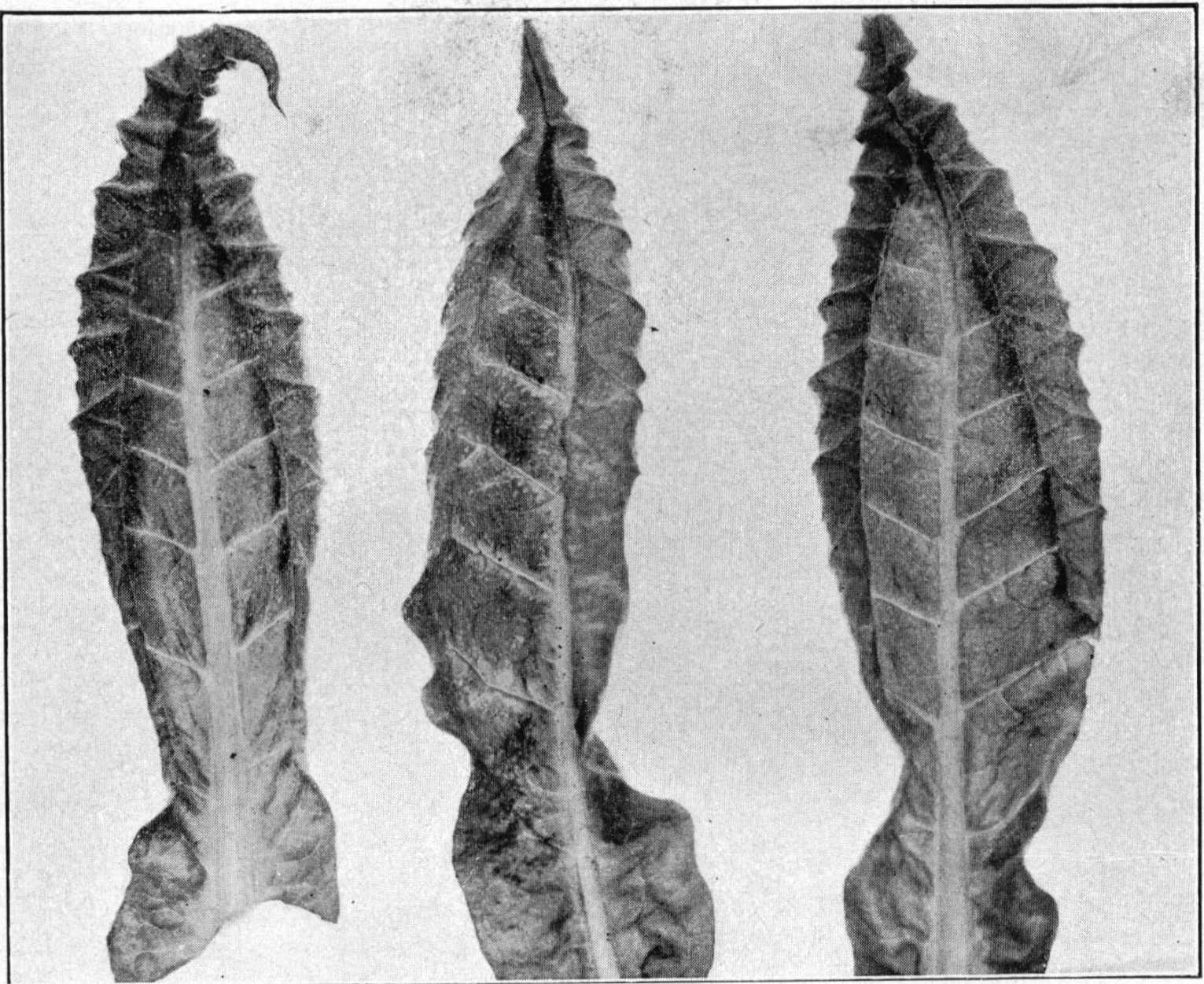

Figura 25 - Nicotiana tabacum var. Creoula. (Fôlhas de plantas afetadas pela forma enrolamento, vistas pela face superior).

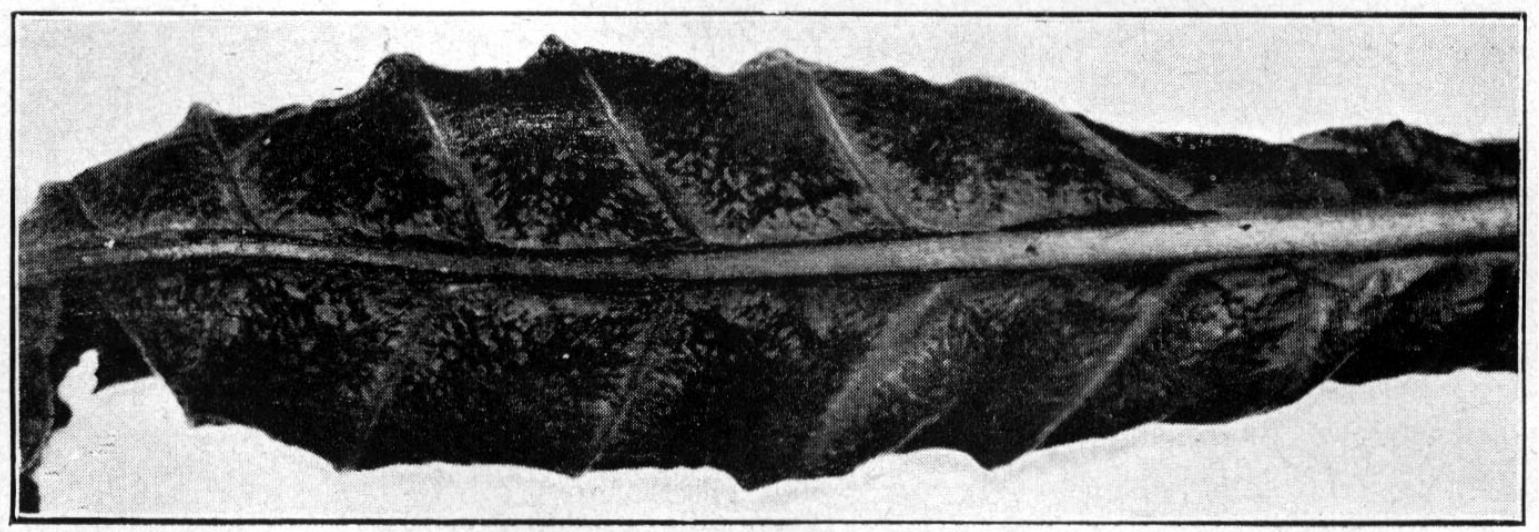

Figura 26 - Nicotiana tabacum var. Creoula. (Fôlha afetada pela forma enrolamento, vista pela face inferior). 
vexos. As nervuras principaís e secundárias das fôlhas que apresentam rugosidade são tortuosas. Vistas pela face dorsal da fôlha mostram um aspecto grosseiro e são translúcidas. Em certos casos, pequenos com. primentos das nervuras de terceira ordem apresentam uma côr verde carreaada, o que pode ser fàcilmente percebido olhando-se a fôlha contra a luz. A presença de excrescências foliares tem sido observada em: certos casos. Nas flores, os sintomas săo bem acentuados, apresentando-se o cálice e a corola bastante corrugados.

Forma enrolamento : esta forma de moléstia é mais rara do que a forma rugosa. Só foi observada nas localidades de Bragança e Limeira. As plantas aletadas sofrem uma redução no porte, e as fôlhas, ao contrário da forma rugosa, fazem um ângulo mais agudo com a parte superior da haste em comparação com aquêle de plantas sadias. 0 siritoma mais notável nesta forma é o enrolamento dos bordos da fôlhà para a face ventral; o ápice da fôlha arqueia-se para cima num plano vertical, curvando-se em direção à haste; o verde da fôlha é, geral. mente, de um aspecto vidrado na face ventral, ao passo que, na lace dorsal, as áreas intercostais mostram a presença de tecidos anormais com aparência esponjosa e de côr verde escura. Além disso, as fôlhas são quebradiças e apresentam excrescências foliares ao longo da nervura principal. Estas tếm vários centímetros de comprimento e cêrca de um milímetro de altura. As flores destas plantas não foram exami nacias.

\section{Etiologia}

Julgamos que esta é uma moléstia de virus, apesar de terem faHecio as nossas tentativas de transmissão por onxertia. A possibilidado d: se tratar de danos causados por ácaros ou outros insetos foi levada em consideração, mas não observamos nada que o comprovasse. Fixiste também a possibilidade de se tratar de uma moléstia fisiológica, mas as observaçōes efetuadas não apoiam esta hipótese.

\section{Contrôle}

Dado o nosso desconhocimento a respeito da causa desta móéstia, una-se difícil sugerir medidas de contrôle. O arrancamento das plar. les atacadas e sua destruiçào a única medida aconselhável neste caso. A. rotação de cultura também. 


\section{IITERATURA CITADA}

$\therefore$ Brieger, F. G. e outros. Ensaio de éfocos de transplante para o fumo. Brajaris 2 : 295.312. 1942.

2. Costa, A. S. e R. Forster. A tranimissão mecânica de vira-cabeça poi fmaja com suco. Inst. Agronòmico. Bol. técn. 50: 1.15. 1939.

3. Costa, A. S. e R. Forster. Uma suspeita de virus do fumo (Nicotiana tubacum L.) semelhante a "Leef curl", presente no Es ado de São Paulo. Jorma: de Agronomia, Piracicaba 2 : 295-302. 1939.

¿. Costa, A. S., A. R. Lima e R. Forster. Necrose branca … uma molés: z is virus do furno (Nicoliana labacum L.) e "tumo couve" como sintoma -... j. . Jomal de Agronomia, Piracicaba $3:$ 1.26. 1940.

3. Costa, A. S. e R. Forster. Identidade do virus de vira-cabega e sua ind no grupo do virus do "spotted-wilt". Bragartia 1 : 491-516. 194j.

6. Costa, A. S. e R. Forster. Notà sôbre a moléstia de virus do fumo denorint at faixa das nervuras. Eragantia 2 : 55.82. 1942.

7. Costa. A. S. e outros. Contribuição para o conhecimento da distribuiça z:ográfica das moléstias do fumo do Estado de São Paulo. Revista de Agrioul. tura. $17: 237-256.1942$.

8. Fawcett, G. L. Enfermedades del tabaco y de los tomates. Em Memoric and: del año 1933. Rev. Ind. y Aqric. Tucuman 24 : 35-36. 1934.

9. Fawcett, G. L. Tabaco. Rm Menoria anual del airo 1934. Rev. Ind. y $A .2$. Tucurnan $25: 153-154.1935$.

10. Fawcett, G. L. Enfermedades del Tabaco. Lim Memoria anual del año 1936 Rev. Ind. y Agric. Tucuniai) $27: 31-32.1536$.

i 1. Fawcett, G. L. Entermedades del tonate y del tabaco. Lim Memoria anual dei año 1938. Rev. Ind. y Agric. Tucuman 29: 37-38. 1939.

2. Fawcett, G. L. Enfermedades de los tormates. Fim Memoria anual ciel año 1941. Rev. Ind. y Agric. Tucuminn $32: 41.45 .1942$.

13. Forster, R. e A. S. Costa. Nota preliminar sôbre a moléstia vira-cabeça do humı. Inst. Agronômico. Bo: técn. 38: 1.12. 1938.

14. Holmes, F. O. Strain of tobacco resistant to tobacco mosaic. Abst. in Phytopath. 28 (1): 9.1938.

15. Johnson, E. M. Virus diseases of tobacco in Kentucky. Kentucky Agr. Exp. Sta. Bull. 306 : 289.415. 1930.

16. Johnson, J. Tobacco streak, a virus disease. Phytopathology $26: 285.292$. 1936.

17. Kramer, M. e Karl Silberschmidt. A "faixa dis nervuras", uma doença de virus do fumo encoritrada no Estado de São Paulo. Arquivos do Institute Biológico 11 : 165.187. 1940.

j8. Lima, A. R. e A. S. Costa. Variedades de fumo resistentes a vira-cabeça. Fer. de Agricultura 15: 133-140. 1940.

: a. Magee, C. J., W. L. Morgan e A. N. Johnston. Control of spotted-wilt of tomatoes. J. Aust. Inst. Agric. Sci. 8: 115-117. 1942.

20. Moore, E. S. The Kromneck or Kat River Disease of Tobacco and Tomato :r: the East Province (South Africa). Union of South Africa Dept. of Agr. Sc. E..i!. 123: 1-28. 1933.

21. Silberschmidt, K. $\bigcirc$ mosaico do fumo. $\bigcirc$ Biológi:o 2 : 381-383. 1936.

22. Silberschmidt, K. A doença "vira-cabeça" do fumo. O Biológico 3 : 18.:-3. 1937. 